\title{
AN ANALYSIS OF, AND DIFFERENT APPROACH TO, CHALLENGES IN FOSTER CARE PRACTICE IN SOUTH AFRICA
}

\section{Annelie Böning, Sandra Ferreira}

\section{INTRODUCTION}

Foster care is perceived to be the best and most widely applied form of alternative care for children besides their maternal home, because it most often occurs within the family context and is supposed to offer safety and protection to children. Despite the various advantages that foster care offers, it is known that foster care practice worldwide including in South Africa - is suffering from serious deficiencies. Therefore it is questionable whether it serves the best interests of the child at all times and whether the principle of social justice is adhered to. As Bass, Shields and Behrman (2004:5) state:

"For too many of these children, foster care is no safe haven. Instead, the children drift from foster home to foster home, lingering in care while awaiting a permanent, forever family."

It is generally known that for various social reasons, foster care practice in South Africa is under great pressure. There are, for example, children who live in unhealthy and unsafe communities where risk factors such as violence, poverty, unemployment, malnutrition and sexual abuse exist. Furthermore, children are often abandoned by parents, or parents just disappear, leaving their children with family or friends. Increasingly, children are left in child-headed households where parents have passed away because of Aids and other illnesses. Children are frequently exposed to various social ills such as alcohol and drug abuse. They ultimately try to survive on the streets and become caught up in child prostitution and criminal activities (South African Society for Prevention of Child Abuse and Neglect, 2003:2).

The social work profession, which is mainly responsible for safeguarding children, is also under pressure because of a shortage of human and other resources. This hampers the quality of foster care services because professional responsibility cannot be taken for all the children in the statutory system. The goals of foster care - namely child protection and development in a safe and healthy environment, rehabilitation, and family reunification (Children's Act 2005:202) - and other more permanent types of alternative care or adoption cannot be properly reached because of these challenges. Seeing that foster care practice in South Africa is primarily influenced by a legal discourse, these challenges also have implications in terms of the fulfilment of stipulations of the Children's Act, children's rights, social work ethics and values such as professional accountability and social justice.

The increase in foster care placements in South Africa is confirmed statistically, with approximately 50000 children placed in formal foster care in 2000 (Law Commission, 2002:54). In 2009 the number of children who received a foster care grant was 511479. This is an increase of 461479 cases over a period of nine years (Children's Institute 2009/2010:108). The Children's Institute's (2009/2010) concern was raised about the 
increase in the large number of children who are dependent on government grants as a result of the effects of poverty and HIV/AIDS. Therefore more and more family members and other caregivers, who have cared for these children over a period of time, try to obtain approval as foster care placements, very often mainly to get access to the foster care grant and basic resources for poverty relief. This is not the primary purpose of foster care. So the question is whether the foster care system is currently being utilised as a poverty-alleviation programme rather than to provide care for poor and orphaned children. The principle of social justice is not adhered to when vulnerable and orphaned children are absorbed into the statutory system for the sake of access to social security. It seems to be appropriate for other programmes to be put in place to address this issue.

The purpose of this article is to present an analysis of the contributing risk factors pertaining to foster care practice in South Africa and to follow a different approach to the practice and the way it is managed. An eco-systemic perspective was applied in the analysis in order to get a holistic view of contributing risk factors as well as on indicators for more effective social work services. To achieve this purpose, the results of a literature review and empirical investigation are presented. The article closes with conclusions and recommendations on the issue.

\section{LITERATURE STUDY}

According to current South African legislation, foster care is the temporary placement of a child who is not available for adoption and whose biological family cannot take care of him or her. A foster parent is an approved person who is not the child's parent or guardian. Preference is given to family placement before non-family members or cluster foster care is considered. Foster care occurs on order by the Children's Court under the supervision of a social worker and a foster care grant is awarded to the foster family (Section 65 of the Children's Act 2005:70; Sections 180 and 186 of the Children's Amendment Act 2007:76; Bosman-Sadie \& Corrie, 2010:201-202).

Foster care placements require time-consuming and expensive investigations by social workers as well as statutory procedures in the Children's Court. A foster care plan must be compiled after the placement with an outline of the foster care supervision services that must be rendered for the duration of the placement. The foster care order must be revised every two years in terms of Section 159 to apply for renewal or discharge of the child. The new amended Children's Act (No. 41 of 2007) allows, in terms of Section 186 , the option of a long-term placement if it can be proven that family reunification is not a possibility. In such cases the child stays in foster care until the age of 18 years. The statutory renewal of the order every two years is no longer expected, although the social worker has to assess continuously if the placement is still in the best interests of the child. This possibility allowed by the Children's Act can bring relief in the workload of the already overloaded social work practice in terms of statutory intervention and report writing.

According to Pretorius and Ross (2010:470,472), foster care placements are predominantly with family members. Family placements are seen as being more 
advantageous than placements with non-related people, because the child can adjust more easily to a familiar environment. This does not mean that these types of placement are less challenging or problem free. Often the relatives and grandparents are poor and overburdened, because they are expected to support the increasing number of orphans and vulnerable children. Children placed in foster care tend to display higher levels of emotional and behavioural disturbances, because they usually come from a deprived economic background, have experienced trauma and may be HIV positive. Therefore social work services involve not only the statutory services but also intensive psychosocial intervention programmes in certain cases.

Another challenge in foster care practice is the shortage of social services practitioners. In terms of the higher expectations of the Children's Act regarding prevention, early intervention and statutory intervention, it has been estimated that 66329 social workers will be needed in South Africa (Children's Institute, 2007/2008:19). Before the new Children's Act (2005) was implemented a costing report revealed that at least 16504 social workers would be needed in 2010/2011 for children's social services. In the latest press release of the South African Institute of Race Relations (2012) it is stated that the shortage of social workers undermines the effectiveness of social welfare legislation. According to this statement, the total number of social workers registered with the South African Council for Social Service Professions was 16740 in March 2012. Of all the registered social workers in the country, the government employs $6655(40 \%)$ and NGOs 2634 (16\%). The other 7451 (45\%) registered social workers are either employed in the private sector or are not practising. Thus, a total of 9289 social workers are responsible for providing the full spectrum of generic social services, including foster care.

Remuneration of social workers as well as funding of social service programmes, especially in NGOs, is also a serious issue. It is general knowledge that social workers in the NGO sector receive a lower salary than those in the public sector. Therefore NGOs have to spend much valuable professional time on fundraising, not only in order to try to pay their staff a proper salary, but also to fund projects and infrastructure. Demands in terms of foster care services are therefore challenging and it is clear that welfare services do not have the necessary infrastructure in terms of human or other resources to fulfil their professional, legal and social responsibilities.

Foster care practice in South Africa is primarily influenced by a legal discourse. This discourse is based on the fact that the law is authoritative, formal and rational, and that accountability before the law dominates any other considerations (Healy, 2005:37). Foster care practice is mainly regulated by the Children's Act, which is grounded in the principles of the Constitution of the Republic of South Africa. Social work practice policy (of which foster care forms a part) is set out in the White Paper for Social Welfare. Human rights and children's rights are highly valued in all these documents. Practice guidelines and protocol for foster care have also been developed to adjust to these policies and legislation. Legislation pertaining to children places a legal liability on social workers to prevent child removal and to improve family preservation as far as 
possible. If removal becomes inevitable, statutory intervention must be rendered to protect the child and to rehabilitate the family of origin (Children's Act 2005: Section 2).

It is difficult to meet these legal and policy obligations in an overburdened practice and to give effect to social justice in terms of the foster child. According to Patel (2005:224), the rights-based approach is founded on the constitutional principles promoting social and economic justice and the equitable distribution of resources favouring the most disadvantaged in the society. It is clear that there is a tension between the fulfilment of foster children's rights and the realities of practice.

In order to get clarity on the above-mentioned issues and to move to possible solutions, an analysis was done on foster care practice in South Africa. An eco-systemic approach was used because of its suitability in investigating complex social issues. Foster care can be regarded as a complex issue because it involves children who are neglected, abused, abandoned or orphaned, and in most cases have been traumatised by multiple factors in the family and/or environment. Rehabilitation and reunification services must also be rendered to the biological family, if they are still involved in the child's life. Foster care supervision services must be rendered to the foster family according to a foster care plan to assist them in fulfilling their responsibilities and rights as foster parents and to support the child's development.

The eco-systemic perspective offers the opportunity for a holistic analysis of the multiple contributing and maintaining factors in foster care practice as social phenomena on the four environmental systems. These systems are described by Ambrosino, Ambrosino, Heffernan and Shuttlesworth (2008:198-199) as micro-, meso-, exo- and macrosystem. According to this description, problems can occur within the individual as the microsystem, the family as the mesosystem, the social structures as the exosystem and the wider social milieu in which families and communities exits as the macrosystem. Within the ecological systems, be they micro-, meso-, exo- or macrosystem, there is ongoing interaction between the risk and protective factors, which can influence the individual's life negatively or positively.

With regard to foster care practice, then, risk factors were identified within the four environmental systems in order to emphasise what should be pursued in an attempt to improve foster care practice in South Africa. In the following section the problem, aim and objectives of the research are formulated. An outline is given of research methods that were followed.

\section{PROBLEM STATEMENT, AIM AND OBJECTIVES OF THE RESEARCH}

This research was guided by the problem that foster care practice is confronted with an increase in the number of children who are dependent on foster care as a result of different social issues, as well as by a shortage in human and other resources.

This article presents an analysis of the risk factors from an eco-systemic perspective in order to identify factors that could improve the quality of foster care services. In order to achieve this aim, the following objectives were used as guidelines: 
- Identify and describe risk factors that presumably lead to the current challenging status of the foster care practice in South Africa;

- Formulate guidelines for the improvement of foster care practice.

\section{RESEARCH METHOD}

The research was of an exploratory and descriptive nature, because foster care was explored and described with reference to a literature study as well as an empirical investigation. The focus was mainly on quantitative results obtained from questionnaires that were used as a data-collection technique. The population consisted of social workers in service offices of the government's Department of Social Development and three types of NGOs that provide foster care services to all the population groups. The data were collected by means of a stratified random sampling method, namely selective probability sampling. This sampling method is best suited for the research because subgroups with homogenous characteristics could be included percentage-wise (Strydom, 2011:230). With such a sampling, each element or segment of the population has the probability to be included (Marlow \& Boone, 2005:138). In this case the four welfare organisations could be seen as sub-groups that are homogeneous with regard to foster care services. A sample was taken from social workers at each of the three NGOs and the sub-samplings collectively constituted the total sampling of social workers who provide foster care services, of which the population was as follows:

- Social workers from child welfare societies with branches countrywide;

- Social workers from organisations of the Dutch Reformed Church, also known as the Christelike Maatskaplike Raad (CMR) in Gauteng, Limpopo, Mpumalanga, North West and the Eastern Cape; Christelike Maatskaplike Dienste (CMD) in KwaZuluNatal; NG Welsyn in the Northern Cape; Badisa in the Western Cape; and the NG Maatskaplike Dienste (NGMD) in the Free State;

- Social workers from institutions that originated from women's organisations, such as Free State Care in Action (FSCIA) in the Free State; the Afrikaanse Christelike Vrouevereniging (ACVV) in the Western Cape, Northern Cape and Eastern Cape; the Natal Christian Women's Association (NCWA) in KwaZulu-Natal and the SuidAfrikaanse Vrouefederasie (SAVF) in Gauteng, the Limpopo, Mpumalanga and North West.

Some of the obstacles that had to be surmounted during data collection included obtaining correct addresses and telephone numbers, long procedures to obtain permission, or to contact authorised persons, or to motivate colleagues to participate. Other problems also included vacant posts or overburdened social workers who could not see their way clear to completing questionnaires. Table 1 shows the various response rates of the returned questionnaires. 
TABLE 1

RATES FOR QUESTIONNAIRES SENT TO WELFARE ORGANISATIONS AND PROVINCES $(\mathrm{N}=68)$

\begin{tabular}{|c|c|c|c|c|c|}
\hline $\begin{array}{c}\text { Geographical } \\
\text { area }\end{array}$ & $\begin{array}{c}\text { Social workers } \\
\text { at Dutch } \\
\text { Reformed } \\
\text { Church } \\
\text { organisations }\end{array}$ & $\begin{array}{c}\text { Social } \\
\text { workers at } \\
\text { women's } \\
\text { organisations }\end{array}$ & $\begin{array}{c}\text { Social } \\
\text { workers } \\
\text { at child } \\
\text { welfare } \\
\text { societies }\end{array}$ & $\begin{array}{c}\text { Social workers } \\
\text { at the } \\
\text { Department of } \\
\text { Social } \\
\text { Development }\end{array}$ & $\begin{array}{c}\text { Total } \\
\text { for the } \\
\text { area }\end{array}$ \\
\hline Free State & 16 & 4 & 4 & 3 & $\mathbf{2 7}$ \\
\hline Eastern Cape & 10 & 1 & 1 & 0 & $\mathbf{1 2}$ \\
\hline Western Cape & 0 & 0 & 12 & 0 & $\mathbf{1 2}$ \\
\hline $\begin{array}{c}\text { KwaZulu- } \\
\text { Natal }\end{array}$ & 1 & 5 & 0 & 0 & $\mathbf{6}$ \\
\hline Northern Cape & 2 & 0 & 2 & 0 & $\mathbf{5}$ \\
\hline North West & 3 & 1 & 0 & 0 & $\mathbf{4}$ \\
\hline Limpopo & 0 & 1 & 1 & 0 & $\mathbf{0}$ \\
\hline Gauteng & 0 & 0 & 0 & 0 & $\mathbf{0}$ \\
\hline Mpumalanga & 0 & 0 & 0 & & $\mathbf{4}$ \\
\hline $\begin{array}{c}\text { Total per } \\
\text { welfare } \\
\text { organisation }\end{array}$ & $\mathbf{3 2}(\mathbf{4 7 . 8 \% )}$ & $\mathbf{1 2}(\mathbf{1 7 . 9 \% )}$ & $\mathbf{2 0}(\mathbf{2 8 . 4 \% )}$ & $\mathbf{4}(\mathbf{5 . 9 \% )}$ & $\mathbf{6 8}$ \\
\hline
\end{tabular}

Of the 138 questionnaires of that were sent out, 68 (49.3\%) were returned. However, the response can be viewed as representative of foster care practice in South Africa, because it was obtained from seven of the country's nine provinces. Furthermore, responses were obtained from all three NGOs that formed part of the sampling and to a lesser degree also from the relevant government department.

Data analysis was done by means of descriptive statistics for quantitative details that were clear from the questionnaires. The questionnaire was divided into different divisions with item numbers to enable electronic processing. A skilled consultant was involved in the composition of a computer package (Delport \& Roestenburg, 2011:196). The quantitative expounding of data enabled interpretations, conclusions and recommendations with regard to the aspects that were included here.

\section{RESEARCH RESULTS AND INTERPRETATION}

Participants in this research consisted mainly of white $(68.7 \%)$, female $(95.5 \%)$ social workers whose ages ranged from their early twenties to retirement age. Only a small percentage had postgraduate qualifications $(7.7 \%)$, but the majority had five years' or more experience. The best feedback $(47.8 \%)$ was received from social workers working for church institutions, while child welfare societies and organisations such as Free State Care in Action were also represented to a large extent. The poorest feedback (6\%) was received from a government institution, the Department of Social Development. The best feedback was received from the Free State (41.2\%), followed by the Eastern Cape and the Western Cape. Some feedback was received from all the other provinces, except Gauteng and Mpumalanga. The researcher works in the Free State and consequently has 
personal contact with welfare organisations, which was advantageous for feedback from the region. ${ }^{1}$

The research results are indicated in the following section under different figures and tables. The first figure (Figure 1) indicates how many children received foster care supervision services in the participants' case loads.

\section{FIGURE 1 \\ NUMBER OF FOSTER CHILDREN IN CASE LOADS OF SOCIAL WORKERS}

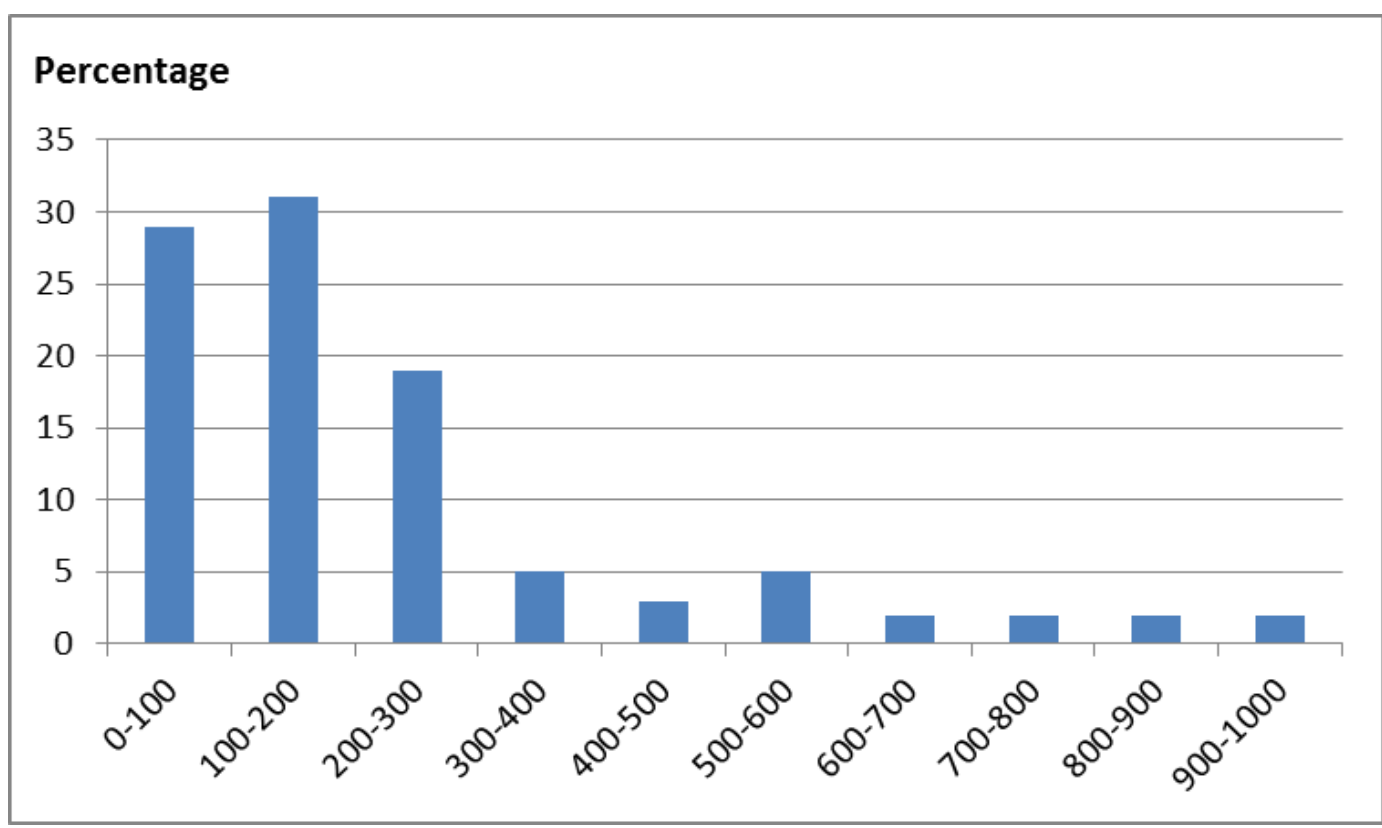

Figure 1 shows that the majority of social workers (31\%) provide services to between 100 and 200 foster children, followed by 100 (29\%) and fewer, and finally followed by 200 to 300 (19\%). Exorbitantly high loads of between 600 and 1 000, and 300 and 500 foster children were reported in single cases. Only foster supervision services to fewer than 100 foster children per social worker can be regarded as being acceptable. Consider that more than one child in a family can be under foster care; therefore the number of foster children can be more than the number of foster families. The acceptability of the number of foster children will also depend on whether or not the social worker involved only provides foster care supervision or is also responsible for other social and welfare legislation work. Because of these high loads, social workers and the welfare organisations find it impossible to accept professional responsibility for the quality of service delivery and to adhere to the principles of social justice.

\footnotetext{
${ }^{1}$ Please note that the analysis and interpretations were done against the background of data obtained from the more stable non-governmental organisations because of the poor response from the government departments. It appears as though government departments have to contend with much greater case loads and challenges.
} 
A further question tested the relationship between family versus non-family placement occurrences in the light of the claims that the latter dominate the practice. The response rates are reflected in Table 2 .

\section{TABLE 2}

\section{FAMILY VERSUS NON-FAMILY FOSTER CARE PLACEMENTS}

\begin{tabular}{|l|c|}
\hline Type of foster care & Percentage \\
\hline Formal foster care with approved non-family members & 23.5 \\
\hline Family placements/Kinship care & 76.5 \\
\hline
\end{tabular}

Non-family foster care (also referred to as formal foster care) implies that the foster parents have been recruited, selected and trained in order to be considered to have an unrelated child placed in their care. Such placements are preceded by a process of suitability to determine which foster parents would best meet the child's needs. Table 2 shows that family placements dominate the case loads of the participants. This concurs with the claims that foster care placements are formalised with families where the children have been taken care of - probably for a considerable period of time - by means of a private arrangement. This means that the welfare organisation is approached with a request for foster care placement, probably to obtain a foster care grant and not to promote social service delivery to the child as such.

The question can be asked whether such placements must be formalised. This can be answered with a brief reference to the Children's Court investigation in the district of Krugersdorp. The case concerned a boy who was brought by his mother in 2002 to live with his aunt and uncle, who raised him like their own child. The mother visited the child from time to time until she passed away in June 2007. The Children's Court was approached in 2010 with a report of the social worker on the suitability of the caregivers as foster parents, because the child was in need of care and protection in terms of section 150(1)(a) of the Children's Act (2005), namely that "a child is in need of care and protection if that child has been abandoned or orphaned and is without any visible means of support". The presiding officer concluded that the child was not in need of care because family members were already caring for him. In coming to this conclusion the presiding officer relied on section 32 of the Act, which provides for voluntary care of a child by someone who has no parental rights and responsibility. This led to an appeal by the Centre of Child Law on behalf of the child to the South Gauteng High Court. The outcome of the appeal was that the interpretation of section 150(1)(a) must be in accordance with sections 27(1) and 28(2) of the Constitution, which deal with the right to have access to social security and the consideration of the paramount nature of what is in the best interest of the child. Thus the child was an orphan and the caregivers did not owe him any duty of material/visible support and therefore such a child should be placed in foster care and is entitled to a foster care grant. This same principle can be applied to grandparents in receipt of an old age pension who are caring for their grandchildren. According to section 180 of the Act, the only people who are excluded from a foster care placement are the biological parents or guardians (Department of Social Development, 2012:1-11). 
Based on this example, family placements can be formalised if it is in the best interest of the child and to have access to social security according to the current social security system. When considering the purpose of statutory intervention and foster care, children should only be taken up into the statutory system as a last resort and not mainly for material reasons. Therefore other options within South African law and the social security system should be investigated at early intervention level to care for and protect these children without necessarily taking them through the costly court system.

Contributing factors in the micro-, meso-, exo- and macrosystem of the ecological context were included in a following question to explore and describe the typical challenges that contribute to the increase of foster care placements. The data related to individual, family and environmental factors leading to foster care placement are reflected in Table 3.

TABLE 3

\section{INDIVIDUAL, FAMILY AND ENVIRONMENTAL FACTORS LEADING} TO FOSTER CARE PLACEMENTS

\begin{tabular}{|c|c|c|c|c|c|}
\hline $\begin{array}{l}\text { Challenges leading to child removal and foster care } \\
\text { placements }\end{array}$ & 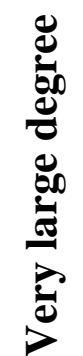 & 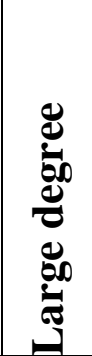 & 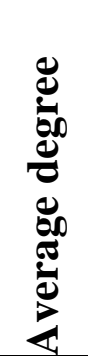 & 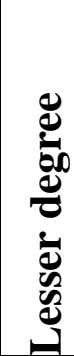 & $\ddot{z}$ \\
\hline & \multicolumn{5}{|c|}{ Percentage } \\
\hline Missing parents and abandoned children & 50 & 35 & 10 & 6 & - \\
\hline Death due to illness such as HIV/Aids and tuberculosis & 66 & 15 & 9 & 7 & 2 \\
\hline Physical neglect & 29 & 27 & 21 & 20 & 3 \\
\hline $\begin{array}{l}\text { Parents shift their child-protection responsibilities to family } \\
\text { or public service delivery institutions }\end{array}$ & 26 & 23 & 33 & 15 & 3 \\
\hline Incompetent parent functioning & 23 & 31 & 19 & 22 & 6 \\
\hline Poverty & 30 & 19 & 19 & 24 & 8 \\
\hline Emotional neglect & 19 & 23 & 32 & 23 & 3 \\
\hline Alcohol and drug abuse & 21 & 25 & 28 & 19 & 6 \\
\hline Emotional abuse & 17 & 14 & 34 & 31 & 5 \\
\hline Unemployment & 24 & 21 & 18 & 29 & 8 \\
\hline Physical abuse & 20 & 14 & 26 & 35 & 6 \\
\hline Inappropriate housing/shelter & 16 & 20 & 23 & 33 & 8 \\
\hline $\begin{array}{l}\text { Single parenthood due to divorce, illegitimacy, absent fathers } \\
\text { or death }\end{array}$ & 20 & 15 & 20 & 31 & 14 \\
\hline Sexual abuse or ill-treatment & 13 & 10 & 35 & 38 & 5 \\
\hline Family violence & 13 & 19 & 22 & 39 & 8 \\
\hline Criminal activities & 8 & 8 & 34 & 32 & 18 \\
\hline Family factors such as marriage/relationship conflict & 5 & 17 & 27 & 36 & 15 \\
\hline Challenging behaviour that parents cannot handle & 12 & 10 & 25 & 36 & 16 \\
\hline Physical disabilities of parents & 9 & 10 & 27 & 43 & 10 \\
\hline
\end{tabular}




\begin{tabular}{|l|l|l|l|l|l|}
\hline Mental disabilities of parents & 8 & 12 & 22 & $\mathbf{3 7}$ & 21 \\
\hline Child rape & 11 & 3 & 20 & $\mathbf{4 6}$ & 20 \\
\hline $\begin{array}{l}\text { Inappropriate punishment regulations like corporal } \\
\text { punishment }\end{array}$ & 5 & 9 & 21 & $\mathbf{4 2}$ & 23 \\
\hline Other (as specified below) & $\mathbf{3 3}$ & $\mathbf{3 3}$ & 11 & - & 22 \\
\hline
\end{tabular}

It would appear that individual factors, such as children with challenging behaviour that parents find hard to handle, play a minor role, while family factors play a major role in contributing to foster care placements. Environmental factors such as poverty, unemployment, alcohol and drug abuse, poor housing and criminal activities range between a large and a lesser degree. It is especially factors relating to parental functioning such as death as a result of illnesses, HIV/AIDS and tuberculosis, missing parents and abandoned children as well as irresponsible and incompetent parenting, which contribute to foster care placements. Physical neglect and abuse as well as emotional neglect and abuse, which vary from a very large to a lesser degree, are also related to incompetent and irresponsible parenting. The cases of sexual abuse and ill-treatment, and child rape are somewhat lower. Other family factors such as family violence, marital or relationship conflict and single parenthood occurred from a moderate to a lesser degree, while physical or mental disabilities of parents occurred mainly to a lesser degree. Participants added the following factors under "Other"' (quoted verbatim):

- 'n Gebrek aan insig van ouerlike verantwoordelikhede by ouers (Parents lack insight into parental responsibilities);

- Fathers not accepting responsibility;

- Wanvoeding (Malnutrition);

- Death, other than HIV,TB;

- HIV symptoms, cannot definitely say HIV;

- Verlate kinders (Abandoned children);

- Een ouer dood, ander ouer onopspoorbaar (One parent deceased, the other missing);

- Weeskinders (Orphans);

- Emosionele verwaarlosing (Emotional neglect).

All the added factors link up with the factors mentioned in the question. It would appear that participants wanted to emphasise these factors, seeing that they were persistent themes that occurred in the results and specifically centred on inappropriate parenting and the death of parents. However, all the factors, be it to a lesser or larger degree, play a role in the increase in foster care placements.

\footnotetext{
${ }^{2}$ All quotations in Afrikaans translated into English by the author.
} 


\begin{tabular}{|c|c|c|c|c|c|}
\hline Aspects of a foster care plan & 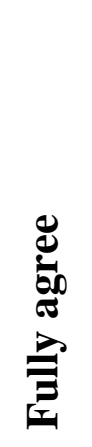 & 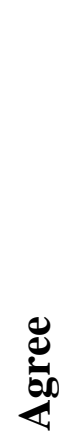 & 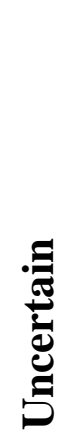 & 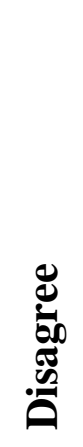 & 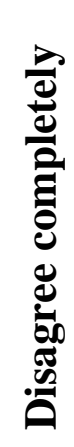 \\
\hline & \multicolumn{5}{|c|}{ Percentage } \\
\hline $\begin{array}{l}\text { Successfully mastering developmental tasks according to } \\
\text { expected milestones is stimulated }\end{array}$ & 54 & 40 & 5 & 2 & - \\
\hline Self-confidence is improved & 54 & 40 & 3 & 2 & 2 \\
\hline $\begin{array}{l}\text { A strength-based approach that creates belief in oneself and } \\
\text { hope for the future }\end{array}$ & 52 & 39 & 8 & 2 & - \\
\hline $\begin{array}{l}\text { Developing a bond that includes positive association with } \\
\text { meaningful adults }\end{array}$ & 48 & 48 & 3 & - & 2 \\
\hline Generosity is encouraged & 48 & 45 & 6 & 2 & - \\
\hline Helpfulness is encouraged & 48 & 43 & 5 & 5 & - \\
\hline $\begin{array}{l}\text { Independence is promoted whereby the child can separate } \\
\text { himself from problematic circumstances and focus on inde- } \\
\text { pendent behaviour and an own existence - empowerment }\end{array}$ & 47 & 42 & 9 & 2 & - \\
\hline $\begin{array}{l}\text { Focus on resilience factors that enable the child to adapt and } \\
\text { develop in spite of dysfunctional circumstances }\end{array}$ & 45 & 31 & 19 & 3 & 2 \\
\hline Physical health is created by appropriate sources & 37 & 54 & 8 & - & 2 \\
\hline $\begin{array}{l}\text { Opportunity for positive ethnic and cultural identity formation is } \\
\text { created }\end{array}$ & 40 & 51 & 8 & 2 & - \\
\hline Spirituality and church membership are encouraged & 41 & 49 & 8 & 3 & - \\
\hline Initiative and competence to solve problems are stimulated & 40 & 49 & 9 & 2 & - \\
\hline Emotional intelligence is promoted & 38 & 41 & 15 & 3 & 3 \\
\hline Humour and dissociation from pain are stimulated & 21 & 39 & 30 & 6 & 3 \\
\hline Other (as specified below) & 25 & 25 & 13 & - & 38 \\
\hline
\end{tabular}

The participants particularly agreed that foster children should have developmental opportunities and should build up their self-confidence. It was fully agreed that a strength-based approach should be followed to give hope to the children. This view was reinforced by the participants' recommendation that bonding/belonging with a family, generosity, independence and resilience factors should be developed. The participants also agreed that resources were needed for physical health, and that the child's right to ethnic, cultural and spiritual identity formation should be recognised. The development of problem-solving skills, emotional intelligence and humour to help them dissociate 
from pain were also agreed on as important factors that should form part of the foster care plan. The following items were added by the participants (quoted verbatim):

- Ondersteuning deur multidissiplinêre spanne bv. Famsa, opvoedkundige hulpdienste (Support from multidisciplinary teams, e.g. Famsa, educational assistance);

- Bogenoemde sou ideaal wees! Nie in realiteit nie (The abovementioned would be ideal! Not in reality);

- Taal bly 'n groot probleem - waarskynlik omdat hulpverlener en kliënt mekaar nie verstaan nie (Language remains a big problem - probably because the person giving assistance and the client do not understand one another);

- Biologiese ouers se rol en verantwoordelikheid moet duidelik wees (The role and responsibilities of the biological parents should be clear).

The assumption is that the placement of every foster child should be managed according to a foster care plan. The content of such a plan was tested by means of the question on aspects of a foster care plan (Table 4$)$.

It is apparent that communication during assistance could be an obstacle considering, for example, that the majority of participants in this study were white social workers who had to provide services to many black foster children and families. Furthermore, it is clear that the social workers were well aware of the content and necessity of a foster care plan, but that the execution of such a plan is not always feasible because of the overloaded foster care practice.

The responses to the next question determined the type of foster families that foster children were being placed in (Table 5).

The following types of families occurred ranging between a very large to an average degree: grandparent households, nuclear families who are related to the child, multigenerative families, single-parent families, and couples with independent adult children and nuclear families who are not related to the child. Childless couples and unmarried couples living together and acting as foster parents occurred to a lesser degree. The other types of foster families as indicated in Table 5 occurred only in single cases. 
TABLE 5

TYPE OF FOSTER CARE FAMILY

\begin{tabular}{|c|c|c|c|c|c|}
\hline Family type & 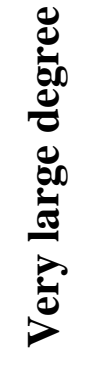 & 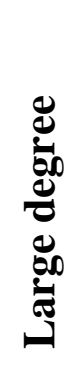 & 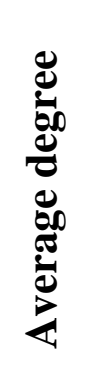 & 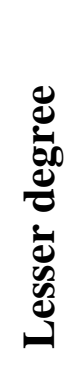 & $\ddot{\tilde{z}}$ \\
\hline & \multicolumn{5}{|c|}{ Percentage } \\
\hline Grandparent households with foster children & 64 & 27 & 6 & 3 & - \\
\hline $\begin{array}{l}\text { Nuclear family, meaning a mother, father and children } \\
\text { who are related to the foster child/family placement }\end{array}$ & 53 & 27 & 16 & 4 & - \\
\hline $\begin{array}{l}\text { Multi-generative families consisting of grand- } \\
\text { parents/parents/ children and other family members and a } \\
\text { foster child/children }\end{array}$ & 33 & 34 & 20 & 9 & 3 \\
\hline $\begin{array}{l}\text { Single-parent families meaning a mother or father with } \\
\text { a foster child/children }\end{array}$ & 25 & 39 & 16 & 10 & 9 \\
\hline $\begin{array}{l}\text { Married couples whose adult children do not live with } \\
\text { them anymore }\end{array}$ & 15 & 27 & 33 & 22 & 3 \\
\hline $\begin{array}{l}\text { Nuclear family, meaning a mother, father and children } \\
\text { who are not related to the foster child }\end{array}$ & 13 & 19 & 34 & 33 & 2 \\
\hline $\begin{array}{l}\text { Married childless couples who take care of a foster } \\
\text { child/children }\end{array}$ & 12 & 5 & 25 & 43 & 15 \\
\hline $\begin{array}{l}\text { Unmarried couples who live together and take care of a } \\
\text { foster child/children }\end{array}$ & 8 & 11 & 20 & 33 & 29 \\
\hline Child-headed households with foster children & 2 & 11 & 20 & 33 & 35 \\
\hline $\begin{array}{l}\text { Restructured families where biological parents, step- } \\
\text { parents, biological children, step-children and foster } \\
\text { children live together }\end{array}$ & 5 & 13 & 19 & 21 & 42 \\
\hline $\begin{array}{l}\text { Non-household families where a group of people live } \\
\text { together and share the responsibility of a foster child }\end{array}$ & 3 & 2 & 12 & 18 & 65 \\
\hline Homosexual couples who serve as foster parents & - & - & 5 & 17 & 79 \\
\hline
\end{tabular}

One participant made the following comment: "Mother very ill and blind - family look after her children." Such an arrangement is related to multi-generative families. Another participant made the following comment with regard to homosexual couples as foster parents: "In white culture, don't occur in black culture." This could confirm the need for further research into multicultural and indigenous foster care practices.

This information confirms that grandparent families mostly function as foster parents followed by nuclear families that are related to the child. This supports the statement that the majority of foster care placements were with family members (Table 2). One of the objectives of foster care is to allow the child to grow up within the normal family 
context, which definitely provides challenges to grandparent families. However, the advantage is that the child can grow up within its well-known family and community context and outside of the institutional context. Again the results link up with dominant themes that have already been identified with regard to parents who have abandoned their children or are dying from AIDS-related illnesses, and family, especially grandparents, who have to take care of the children and depend on a foster care grant. Thu, the question arises whether the grandparents, especially, would be able to lead the child through all the developmental phases, taking into consideration the great age difference and the lack of continuous foster care services. Such family structures undoubtedly face challenges in terms of acting in the best interest of the child.

The question reflected in Figure 2 tested the general financial position of foster parents, seeing that in practice it is usually assumed that the foster family has an independent income at their disposal and should not be dependent on the foster care grant that should be used to fulfil the child's needs.

\section{FIGURE 2}

\section{MONTHLY INCOME OF FOSTER FAMILIES}

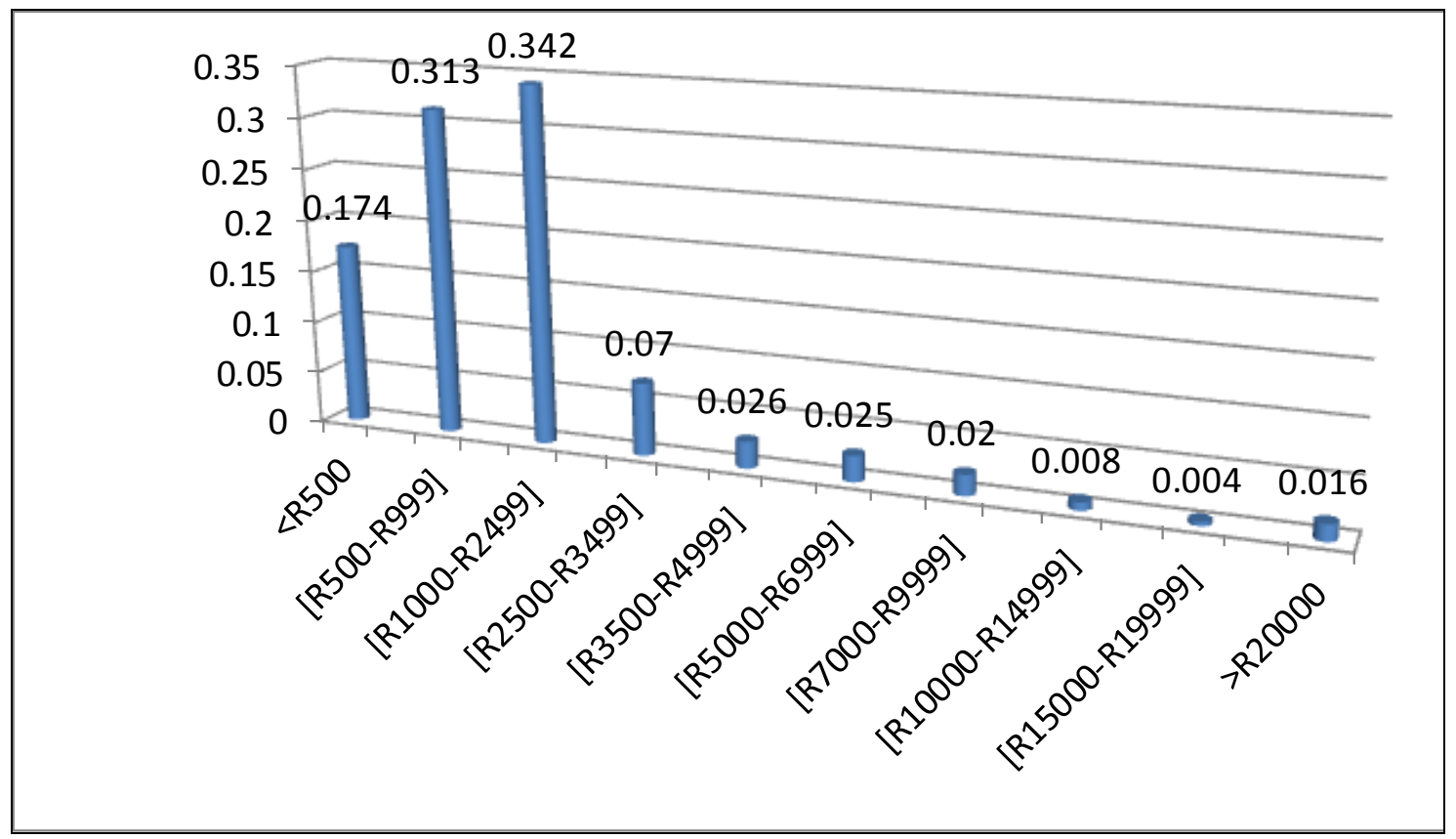

According to the majority of participants, foster parents earn a monthly income of between R1 000 and R2 499 (34\%), where after it decreases to between R500 and R999 (31\%). Certain participants indicated that the foster care grant (about R700 during 2009) had already been calculated into this income, while two others indicated that the grant had not been calculated into this income. In many cases there was more than one child in foster care, which indicated that the grant might be the only fixed family income. Again this strengthens the argument that foster care is used for poverty relief and that the child does not receive the full benefit of the grant. It is also possible that the children had been abandoned by their parents or that the parents had died and that their relatives were taking care of them to the best of their ability, despite their poverty. 
The question reflected in Table 6 was linked to the previous question (Figure 2) to ascertain whether a parallel existed between the income source and the work position of the foster family and to what extent the foster families were economically productive.

TABLE 6

WORK SITUATION OF FOSTER PARENTS

\begin{tabular}{|c|c|c|c|c|c|}
\hline & 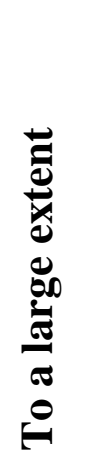 & 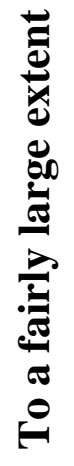 & 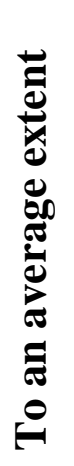 & 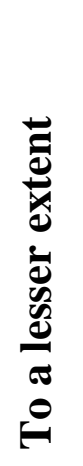 & $\begin{array}{l}\overline{\bar{\sigma}} \\
\bar{\sigma} \\
\bar{\theta} \\
\bar{z}\end{array}$ \\
\hline & \multicolumn{5}{|c|}{ Percentage } \\
\hline $\begin{array}{l}\text { Dependent upon other government grants apart from } \\
\text { foster parent allowances }\end{array}$ & 46 & 33 & 12 & 6 & 3 \\
\hline Unemployed & 42 & 29 & 12 & 15 & 2 \\
\hline Foster parent allowance is the only fixed income & 26 & 26 & 21 & 15 & 12 \\
\hline $\begin{array}{l}\text { Permanent position in working class but without any } \\
\text { extra benefits such as a medical fund }\end{array}$ & 17 & 26 & 32 & 21 & 4 \\
\hline Informal work/own informal business & 23 & 24 & 27 & 18 & 8 \\
\hline Working class with extra benefits & 2 & 8 & 22 & 49 & 19 \\
\hline Professional working class with extra benefits & 2 & 8 & 10 & 58 & 22 \\
\hline Own business/Business sector & 5 & 3 & 9 & 43 & 40 \\
\hline Other (as specified below) & & 33 & & 17 & 50 \\
\hline
\end{tabular}

From the results it can be concluded that the majority of participants were of the opinion that foster parents are dependent on government grants, which could include child support grants and old-age pension (grandparent placements). In certain cases the foster care grant was the only income of the family, ranging from a very large to a moderate degree. To a large extent the foster parents were unemployed or did have a job but without any benefits, or they attempted to obtain an income through informal work, which did not offer any security. One participant referred to "temporary contract work". Only a few foster parents were involved in the working or professional class, with benefits, and had a trade or profession. Thus very few of the foster families could provide for themselves independently or maintain an average to above-average lifestyle that offered security to a family. These results confirm the socio-economic reality of unemployment, poverty and the apparent perception that foster care grants can be seen as a source of family income. 
The question on family reunification services sought to determine the validity of the popular statement that family reunification services only materialise in single cases and that children are often placed in long-term foster care.

FAMILY REUNIFICATION SERVICES

\begin{tabular}{|c|c|c|c|c|c|}
\hline & 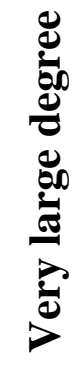 & 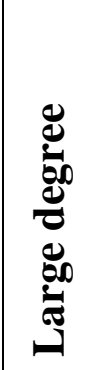 & 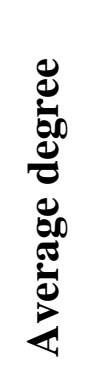 & 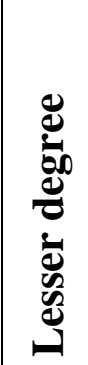 & $\stackrel{\mathscr{Z}}{Z}$ \\
\hline & \multicolumn{5}{|c|}{ Percentage } \\
\hline Biological parents are deceased, no services & 66 & 18 & 10 & 3 & 3 \\
\hline Biological parents are missing, no services & 47 & 31 & 13 & 6 & 3 \\
\hline $\begin{array}{l}\text { Biological parents sporadically involved with a small chance of } \\
\text { family reunification }\end{array}$ & 12 & 32 & 21 & 28 & 7 \\
\hline $\begin{array}{l}\text { Biological parents are involved with children but replacement } \\
\text { is not feasible due to long-term/permanent deficiencies like } \\
\text { chronic illnesses or imprisonment }\end{array}$ & 2 & \begin{tabular}{|l|}
12 \\
\end{tabular} & 25 & 50 & 12 \\
\hline $\begin{array}{l}\text { Biological parents who are actively involved in the family } \\
\text { reunification programme with a strong replacement probability }\end{array}$ & 2 & 8 & 21 & 54 & 16 \\
\hline Other (as specified below) & 13 & 25 & 25 & - & 38 \\
\hline
\end{tabular}

The results indicate that the participants were of the opinion that family reunification services were not provided to a very large degree, because parents were deceased or missing. Only in a small percentage ( $2 \%$ very large degree) did the possibility of reunification or involvement of the biological parents exist, although reunification was not feasible because of chronic or long-term problems. Furthermore, certain biological parents were only involved sporadically (12\% very large degree), which made family reunification impossible. Participants added the following (quoted verbatim):

- Een ouer oorlede, een onopspoorbaar (One parent deceased, one missing);

- Unknown fathers demanding family re-unification years after placement;

- Biological parents uncooperative;

- Biological parents unknown.

The recurring theme is that family reunification is only feasible in extraordinary cases and that children are reliant on long-term foster care. Legislation compels social workers to provide family reunification services as long as there is contact with the biological parents. This means that social workers must report biannually with regard to the possibility of reunification, unless it can be proven that it is excluded as constituted in Section 186 of the Children's Amendment Act (2007:76). In such cases the foster care 
placement is only monitored biannually to evaluate whether the placement is still in the best interest of the child. This section can bring relief in terms of statutory obligations and make the workload of the foster care practitioner more manageable.

A question regarding behavioural, emotional and physical problems with foster children (Table 8) was included, because there are claims that multiple problems with foster children are experienced that are difficult to identify and to treat in the overloaded foster care practice, to prevent failed placements.

\section{TABLE 8 \\ BEHAVIOURAL, EMOTIONAL AND PHYSICAL PROBLEMS WITH FOSTER CHILDREN}

\begin{tabular}{|c|c|c|c|c|c|}
\hline & 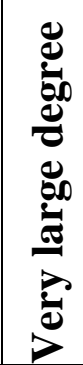 & 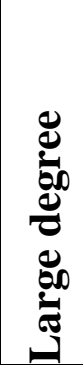 & 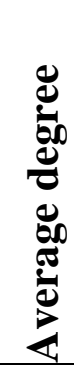 & 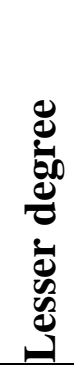 & $\stackrel{\mathscr{E}}{Z}$ \\
\hline & \multicolumn{5}{|c|}{ Percentage } \\
\hline Challenging behaviour & 7 & 29 & 41 & 19 & 3 \\
\hline Poor self-image and identity crisis & 9 & 14 & 49 & 25 & 3 \\
\hline Aggressive behaviour & 4 & 22 & 43 & 24 & 7 \\
\hline Truancy & 6 & 15 & 45 & 28 & 6 \\
\hline Substance abuse & 5 & 21 & 27 & 39 & 9 \\
\hline Anxiety & 4 & 9 & 34 & 50 & 3 \\
\hline Physical problems, for example, stomach ache, headache, asthma & 4 & 9 & 22 & 57 & 7 \\
\hline Withdrawal from other people and activities & 2 & 3 & 28 & 52 & 15 \\
\hline Criminal behaviour & - & 4 & 24 & 59 & 13 \\
\hline Enuresis & - & - & 20 & 62 & 18 \\
\hline Eating disorders & 3 & 4 & 10 & 40 & 43 \\
\hline Sleeping disorders & - & 3 & 15 & 65 & 17 \\
\hline Encopresis & - & 2 & 8 & 54 & 37 \\
\hline Other (as specified below) & 18 & 46 & - & 18 & 18 \\
\hline
\end{tabular}

From the results it appears that the highest percentages of behavioural and psychological problems are indicated under average degree. Considering very large, large and average degree, it appears in the order of challenging behaviour, poor self-image and identity crisis, aggressive behaviour and truancy. Single problems indicated as the highest percentage under lesser degree are substance abuse, physical or health problems, social withdrawal, criminal behaviour, enuresis, eating and sleeping disorders and encopresis. Participants added the following problems (quoted verbatim):

- Girls falling pregnant at 15 ;

- Promisku/seksueel aktief (Promiscuous/sexually active); 
- Seksuele losbandigheid (Sexual licentiousness);

- Gedragsprobleme a.g.v. leerprobleme (Behavioural problems as result of learning problems);

- Minder opvallend bv. angstigheid ens. nie so baie soos bv. aggressiewe gedrag nie (Less conspicuous, e.g. anxiety etc. Not as much as aggressive behaviour, for example) (The probable meaning is that emotionally related problems are overlooked in relation to the child's challenging behaviour - author);

- Taal is 'n probleem om werklik by emosionele aspekte van die pleegkind uit te kom. Ongedissiplineerdheid is die heel grootste probleem, omdat swart ouers nie weet hoe om dit toe te pas nie (Language really poses a problem when trying to get to the emotional aspects of the foster child. Undisciplined behaviour is the biggest problem, because black parents do not know how to enforce discipline);

- Omdat ons min kontak met die kind het, bestaan daar nie altyd 'n sterk vertrouensverhouding nie. Kinders praat dus nie oor die oorsaak van sy gedrag nie (A strong trust relationship does not exist, because we do not have much contact with the child. Therefore, children do not speak about the cause of their problems).

Although the results do not point to a high occurrence of problems, this is doubt about whether the full extent is known. If the high case loads are taken into account, the question can be asked whether the supervisory social worker could identify problematic behaviour with only periodic visits and whether the foster parents who are dependent on the foster care grant for a living report the behaviour. Usually, the issue is raised only when it has already reached a critical stage.

The aim of the question on foster care supervision services (Table 9) was to determine what is applied in practice at intervention level during foster care supervision services.

It is clear that intervention is mostly done by means of the case work method, after which referral to other assistance professions and group work with the children occurs. Community work is applied to an average and lesser degree. Other forms of assistance such as medical or health services, play therapy, educational services, pastoral assistance and adventure-based therapy are used to a lesser degree. One participant added: "Adventure therapy is being planned for later" and another remarked: "Psychological treatment - poor. Every time another person (probably a psychologist) to see. Start again from beginning." 
TABLE 9

FOSTER CARE SUPERVISION SERVICES

\begin{tabular}{|c|c|c|c|c|c|}
\hline Assistance methods & 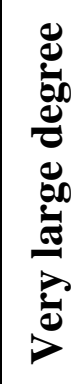 & 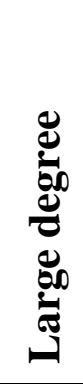 & 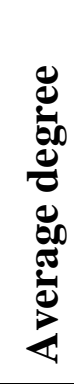 & 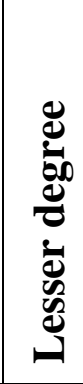 & $\stackrel{\mathscr{z}}{Z}$ \\
\hline & \multicolumn{5}{|c|}{ Percentage } \\
\hline Case work intervention & 52 & 37 & 7 & 4 & - \\
\hline $\begin{array}{l}\text { Referral to/collaboration with other assisting professions such as } \\
\text { occupational therapy or psychology }\end{array}$ & 12 & 24 & 28 & 36 & - \\
\hline Group work with children who have similar problems & 12 & 27 & 24 & 35 & 3 \\
\hline Community work with educational and guidance sessions & 7 & 18 & 34 & 31 & 10 \\
\hline Medical services & 5 & 22 & 28 & 34 & 10 \\
\hline Play therapy & 6 & 9 & 31 & 34 & 19 \\
\hline Educational services for learning disabilities & 9 & 16 & 18 & 43 & 15 \\
\hline Pastoral/spiritual assistance sessions & 2 & 10 & 22 & 52 & 15 \\
\hline Adventure-based therapy & 3 & 5 & 6 & 22 & 64 \\
\hline Other (as specified below) & - & - & - & 40 & 60 \\
\hline
\end{tabular}

The method of assistance that is used most often - namely case work - is also the most expensive, because it occurs on a one-to-one basis. The question can be asked whether more group work might be possible because the circumstances of the majority of foster care placements are similar. According to the results, there is a relatively low occurrence of assistance regarding the handling of behavioural problems. It is also possible that in some cases there is insufficient handling, because monitoring does not occur consistently.

It is assumed that foster care placements should be monitored continuously and that effect should be given to a foster care plan in order to compile six-monthly progress reports in which services are evaluated to eventually make a recommendation about possible family reunification or permanence planning, after two years. Data on the frequency of foster care supervision services is presented in the following table.

TABLE 10

FREGUENCY OF FOSTER CARE SUPERVISION SERVICES

\begin{tabular}{|l|c|}
\hline & Percentage \\
\hline Every term & 36.8 \\
\hline Biannually & 23.5 \\
\hline Annually & 23.5 \\
\hline Monthly & 10.3 \\
\hline Less & 4.4 \\
\hline 1-2 weekly & 1.5 \\
\hline
\end{tabular}


From the results it appears as if monitoring is mostly done quarterly, followed by annually and biannually. With the high case loads taken into account, foster supervision services are provided on a fairly regular basis. However, if the results shown in Table 10 are compared with the data reflected in Figure 1, the content and quality of such services are questionable, because in view of the high case loads it is impossible to be intensively therapeutically involved. That can also explain the results shown in Table 8 regarding the awareness of the extent to which behavioural, emotional and physical problems occur in foster care placements. Service delivery is probably attuned to the fulfilment of statutory commitments such as renewing the order after two years in order for the foster care grant to be paid out.

The most important results of the research are reflected in the above section. Conclusions and recommendations based on the literature and empirical study are subsequently presented.

\section{CONCLUSIONS AND RECOMMENDATIONS}

The following conclusions are drawn in terms of the analysed risk factors and challenges in foster care practice.

- Based on the literature study, foster care is seen worldwide as the best form of alternative care for children in need of care and protection, because it occurs within a family structure. Despite the advantages of foster care, the status of the practice in South Africa is currently overburdened with several challenges. The most important contributing factors to this status are the increasing number of children in the system, mainly due to dysfunctional family structures, HIV/AIDS-related deaths and poverty. Furthermore, social work practice has to deal with the demands of new child legislation in terms of prevention, early intervention and statutory intervention services. The shortage of social services practitioners and the lack of funding to nongovernmental child protection organisations are seen as obstacles in the way of improving the effectiveness of the practice.

- According to the empirical investigation, the social workers who took part in the survey are mostly practising in non-governmental organisations and are challenged daily with overburdened foster care practice (Figure 1). Their participation is highly valued, because it contributes to the compilation of a scientific base for several issues that are constantly under discussion as well as to the exploration of possible solutions.

- The extremely high case loads that social workers have to deal with and that could have a demoralising effect on work performance are confirmed in Figure 1.

- All the factors mentioned in Table 3 play a role in the increase of foster care placements to a lesser or greater degree, although family factors (the mesosystem) seem to be the most important in terms of HIV/AIDS-related deaths and parents not taking responsibility for the care of their children. 
- The prevalence of poverty and unemployment (the exosystem) plays a meaningful role in the increase of foster care placements and could contribute to the fact that parents sometimes leave their children in family care - especially with the grandmothers - and then disappear. The majority of these situations are transformed into foster care (Figure 1 and Tables 2 and 3.)

- Foster care grants are not always utilised in the best interest of the child's physical, emotional, intellectual or social needs, because numerous foster children are placed with poor family members. In these cases the grant becomes part of the family's total income in which all the occupants share (Figure 2; Table 6). The foster care system is therefore being used for poverty relief and to care for orphans, when other regulations and measurements outside of the costly statutory system, more on the macro level, should be in place to address these issues.

- The majority of foster parents are unemployed, with their only source of income being government grants and pensions, or income from informal work (Table 6). The demand for foster care grants, especially, has increased drastically. The fact that the amount is greater than the child support grants could play a role in these cases. There is concern that children are being abused to obtain foster care grants and that the focus of welfare services on social security is becoming too prominent.

- The lack of effective social work services has a negative influence on the quality of foster care placements. The focus of services in practice mainly centres on administrative and statutory processes. High case loads obstruct in-depth intervention, especially in the microsystem in terms of therapy to individual children, and social workers are constantly overloaded. The most extensively used individual social work method for assistance, namely case work, is also the most expensive working method and therefore social workers have to reconsider the way in which they manage their foster care caseloads (Tables 8 and 9).

- Foster children are mostly placed with family members such as grandparents or related nuclear and single-parent families (Tables 2 and 5). This is not the ideal family structure for children to develop and grow in. However, this is still a better option of alternative care than an institution, but on condition that social work services are available to attend to the emotional and psychological needs of both the foster child and the family to ensure a successful placement.

- The reality in South Africa is that family reunification services are realised in the minority of cases, because most parents are deceased or missing, and those who are available are mainly uninvolved or caught up in chronic problems (Table 7). Statutory obligation to report on the status of the placement every second year can be relieved with the option offered in Section 186 in the Children's Act, when reunification can be terminated for proven reasons.

- The real purpose of foster care, namely to rehabilitate the parents and to reunite the biological family, does not occur in the majority of cases and therefore a more permanent bond between caregiver and child should be established through long-term 
foster care. A foster care placement should empower and protect the child in the process of normalising, socialising and internalising in society. The reality is that most foster children grow up in impoverished circumstances, where the emphasis is on satisfying their basic needs and not on intervention and development.

- The legal discourse is dominant in foster care practice and therefore the authorities should give serious attention to enabling social workers to meet the required legal and professional obligations. Social workers cannot render proper foster care services without the necessary infrastructure. Ethical dilemmas ensue because the challenges of practice cannot be met while professional responsibility should be accepted for the full spectrum of services to every foster care case registered at the organisation.

- The eco-systemic perspective is a suitable theoretical framework within which to analyse foster care practice. It ensures a holistic in-depth approach, because the person within the environment in which he/she is functioning can be analysed in terms of different environmental systems from micro- to macro-level.

It can be concluded that the aim of the research was attained, because it was possible to present an analysis of risk factors in foster care practice. Several recommendations are consequently made for the improvement of foster care practice in South Africa.

- A foster care plan should exist for each foster child that deals with objectives according to identified needs, a time schedule within which objectives should be reached and the responsible person for executing the plan.

- Persons from other social services, such as auxiliary workers, child- and youth-care workers and community developers, should be made more readily available to the foster care practice. Such career groups can provide preventative services and monitor long-term family placements that do not require intensive intervention. In such a way effect can be given to the regulations of new child legislation in terms of prevention and family preservation. Social work has been declared as a scarce human resource and should therefore primarily be applied towards intensive psychosocial programmes to realise the purpose of foster care for the sake of the best interests of the child.

- More funding and resources should be made available particularly to nongovernmental organisations for proper remuneration of social workers and to fund social work programmes.

- Community work programmes and group sessions to promote parenting skills for the purposes of family preservation should be prioritised in service delivery and in the allocation of subsidies.

- Child protection organisations should make greater claims to parents where children live in risky circumstances, in order that they first meet their parental responsibilities before children are taken up into the statutory system. 
- A better tracking system should be negotiated with the police services to find parents who abandon their children and have them accept responsibility for especially material maintenance by involving the Maintenance Court.

- Another social security benefit should be developed for the benefit of family members caring for orphans and that is more comparable to the foster care grant (R720) than the child support grant (R270), in order to decrease the pressure on the foster care system for the care of orphaned or abandoned children. Children's Court procedures must be based on children in need of care and not in need of cash.

- The foster care system should not be used as a poverty-relief programme at the cost of professional assistance to foster children who could benefit from rehabilitation and family reunification.

- Social development includes economic development and therefore poverty-relief programmes should be tackled interdepartmentally and in association with, for instance, housing, health and education to be more accessible to everyone, with a specific focus on self-empowerment and the promotion of independence.

- Guidance and information programmes for the public ought to be provided by the Department of Social Development and NGOs, with regard to the expectations of professional social work services. This is to ensure that social workers are not primarily associated with material assistance and foster care placements as a gateway to foster care grants.

- In order to make the work load of the foster care practitioner more manageable, foster care services should not predominantly be provided on an individual basis through case work. It should rather be done in group context by means of training and monitoring groups for foster parents and groups for foster children designed according to identified needs.

- The provision of Section 186 of the Children's Act to extend long-term family placements for more than two years at a time until the child turns 18 must be applied by social workers in order to relieve the pressure of biannual renewals and to improve the management of case loads.

- Indigenous customs within African culture, where it is common practice that parental role fulfilment is shared within the family or community system, could be strengthened. This can be done by cultivating and encouraging additional support to single parents and grandparent households. Support is especially necessary to compensate for the loss of a father figure or other deficits families may experience in terms of discipline or extra stimulation for the children.

In conclusion, it can be stated that foster care practice is mainly regulated by the Children's Act, based on the principles of the Constitution of the Republic of South Africa, which values human rights and children's rights highly. From the information provided in this article it is clear that at present children end up in the statutory system, while professional responsibility cannot really be accepted for them. Therefore foster 
care practice can be seen to be experiencing a crisis and the question can be asked whether it is really serving the best interests of the child and adheres to the value of social justice. An attempt has been made in the recommendations to motivate the reader, policy and legislative developers and foster care practitioners to consider a different approach to managing the challenges that have been mentioned here instead of accepting the current situation.

\section{REFERENCES}

AMBROSINO, R., AMBROSINO, R., HEFFERNAN, J. \& SHUTTLESWORTH, G. 2008. Social work and social welfare: an introduction $\left(6^{\text {th }} \mathrm{ed}\right)$. Belmont: Thomson.

BASS, S., SHIELDS, M.P.A. \& BEHRMAN, M.D. 2004. Children, families, and foster care: analysis and recommendations. The future of children, 14(1):1-28. [Online] Available: www.futurechildren.org. [Accessed: 28/09/2004].

BOSMAN-SADIE, H. \& CORRIE, L. 2010. A practical approach to the Children's Act. Durban: LexisNexis

Children's Act No. 38 of 2005. See SOUTH AFRICA (Republic). 2005.

Children's Amendment Act No. 41 of 2007. See SOUTH AFRICA (Republic). 2007.

CHILDREN'S INSTITUTE. 2007/2008. Child Gauge. Cape Town: University of Cape Town.

CHILDREN'S INSTITUTE. 2009/2010. Child Gauge. Cape Town: University of Cape Town.

DELPORT, C.S.L. \& ROESTENBURG W.J.H. 2011. Quantitative data collection methods: questionnaires, checklists, structured observation and structured interview schedules. In: DE VOS, A.S., STRYDOM, H., FOUCHÉ, S.B. \& DELPORT, C.S.L. (eds) Research at grass roots: for the social sciences and human service professions $\left(4^{\text {th }}\right.$ ed). Pretoria: Van Schaik Publishers.

DEPARTMENT OF SOCIAL DEVELOPMENT. 2012. A synopsis of the judgment of SS $V$ the presiding officer of the children's court: District of Krugersdorp and others. Department's Chief Directorate: Legal services.

HEALY, K. 2005. Social work theories in context: creating frameworks for practice. New York, NY: Palgrave Macmillan.

LAW COMMISSION. 2002. See SOUTH AFRICA (Republic).

MARLOW, C.R. \& BOONE, S. 2005. Research methods for generalist social work ( $4^{\text {th }}$ ed). Belmont: Brooks/Cole.

PATEL, L. 2005. Social welfare social development in South Africa ( $5^{\text {th }}$ impression). Cape Town: Oxford University Press.

PRETORIUS, E. \& ROSS, E. 2010. Loss, grief and bereavement: the experiences of children in kinship foster care. Social Work/Maatskaplike Werk, 46(4):469-485. 
SOUTH AFRICAN INSTITUTE OF RACE RELATIONS. 2012. Press Release on Social worker shortage undermines effectiveness of social welfare legislation. [Online] Available: www.sairr.org.za.

SOUTH AFRICA (Republic). 2002. Law Commission. Discussion paper 103: review of the Child Care Act. Project 110: ISBN 0-621-31810-8. Pretoria: Government Printer.

SOUTH AFRICA (Republic). 2005. Children's Act, No. 38 of 2005. Pretoria: Government Printer.

SOUTH AFRICA (Republic). 2007. Children's Amendment Act, No. 41 of 2007. Pretoria: Government Printer.

SOUTH AFRICAN SOCIETY FOR PREVENTION OF CHILD ABUSE AND NEGLECT. 2003. Children's Bill: submission on child protection, incorporating prevention and early intervention and children in especially difficult circumstances. Johannesburg: Unpublished report.

STRYDOM, H. 2011. Ethical aspects of research in the social sciences and human service profession. In: DE VOS, A.S., STRYDOM, H., FOUCHÉ, C.B. \& DELPORT, C.S.L. (eds) Research at grass roots: for the social sciences and human service professions $\left(4^{\text {th }}\right.$ ed). Pretoria: Van Schaik Publishers.

Dr Annelie Böning; Dr Sandra Ferreira, Department of Social Work, University of the Free State, Bloemfontein, South Africa. 


\section{A PROCESS EVALUATION OF A PROGRAMME FOR STREET PEOPLE}

\section{Kevin O'Donoghue, Joha Louw-Potgieter}

\section{INTRODUCTION}

The plight of the homeless in South Africa has been graphically described by Cross and Seager (2010a:18) as "the proverbial skeletons at the feast, the excluded poorest who enter unobserved and stand by gaunt and starved, terrifying to the invited guests but deprived of any capacity to join the party."

The challenges which homeless people face every day are numerous and are not likely to be overcome with any ease. These challenges include hunger, malnutrition, disease, crime, abuse, violence, mental illness, exposure to the elements and difficulty in accessing government services. The homeless may also experience isolation and difficulties integrating into mainstream society. The severity of these challenges in combination with the lack of data on South Africa's homeless suggests that permanent solutions to homelessness will be challenging.

Seager and Tamasane (2010) conducted a survey of the health problems of the street homeless in South Africa. The results of the survey showed that one out of every five homeless people had experienced assault or had been injured in some way within the previous six months. Twelve per cent of homeless adults and almost $7 \%$ of street children under the age of 18 could be considered to be disabled. More than half of the adults had experienced symptoms of depression during the previous 30 days. It was also noted that street people are at risk for contracting the human immunodeficiency virus (HIV) or other sexually transmitted diseases as "they tend to be sexually active from a young age, have more partners, are less likely to use condoms, tend to use alcohol and drugs more frequently than other groups (which may impair their decision making about safe sex), and they are vulnerable to rape and 'survival sex' (sex in exchange for food and other essentials)" (Seager \& Tamasane, 2010:76).

These challenges for the homeless are not restricted to South Africa. Results of a needs assessment (Herman, Streuning \& Barros, 1994) among the homeless in New York City showed that the most common need was finding a place to live, while the next most pressing need was for employment or income. Other needs included the resolution of health problems and help in obtaining public assistance. The authors argue that the multiple needs of the homeless suggest that any programme which seeks to help them must be able to grant access to multiple services.

In an evaluation of a multi-site programme in the United States, Rog (1999) found that homeless families had multiple needs, including access to mental and physical health services, substance abuse treatment, and education and training. She also noted that domestic violence and poor mental health were the most prominent challenges which homeless women faced. 
Numerous organisations have risen to the challenge to assist homeless people to leave a life on the street and integrate into mainstream society. These organisations have to address the many difficulties which the homeless face on a daily basis.

The implementing organisation of the programme under evaluation is one such an organisation which faces these challenges in its attempts to assist clients to move from the streets into mainstream society. This article aims to provide a process evaluation of its street person's programme.

\section{Programme description}

The following programme description was obtained from the implementing organisation's website, programme documents and discussions with the programme manager.

The implementing organisation is a non-governmental (NGO), faith-based organisation which is located in Cape Town, South Africa. It receives funding from its umbrella organisation and the Western Cape Provincial Government. The aim of the NGO's street person's programme is to help clients move into permanent accommodation. In order to achieve this, it is believed that the clients need to achieve three objectives. First, they have to find employment; secondly, they need to find temporary or long-term shelter; and thirdly, they need to assess the reason why they are living on the street and if possible, to find a permanent solution to this state.

Underpinning these three objectives are additional services offered by the NGO. These additional services do not have a direct causal relationship with the goal of getting clients off the street, but without these services it is likely that the programme would be unsuccessful. These five services entail the provision of food, hygiene, primary health care and emotional support, and assisting clients to access relevant state services. These services, plus a drug rehabilitation service, are offered from the premises of a single centre. The centre does not offer sleeping facilities.

The target population of the programme is the street homeless over the age of 16 years. Four categories of service are offered to the target population: provision for physical needs; provision for social needs; skills training and the creation of employment; and spiritual programmes. However, these services are resource-dependent and as such are not always readily available. Furthermore, the NGO generally offers services to clients only for three months in order to avoid creating dependence. These services are described in more detail below.

\section{Provision for physical needs}

The NGO attempts to address the physical needs of their clients by providing storage lockers, showers, toilets and laundry facilities. Food parcels are handed out and clients can cook food on the NGO's premises.

Clients are offered primary health care including oversight of the administration of medication for pulmonary tuberculosis (TB) and HIV. Clients who attend out-patient 
rehabilitation treatment are given letters which they may present to a nearby shelter to secure a bed.

Limited funding is provided to clients who wish to travel back to their original home. A special fund was created for providing clients with building materials for erecting shacks.

\section{Provision for social needs}

Clients are offered a voluntary psychosocial evaluation in order to determine their needs. A social worker administers this evaluation and also offers other services including the running of support groups, helping clients attend hospital visits, and reuniting clients with their families when appropriate.

The NGO tries to care for their clients' social needs by providing an outpatient rehabilitation programme for substance abusers. This programme is run by a health professional. Personal counselling is also offered by a member of the programme staff.

The NGO also offers advice on how to obtain identity documents, pensions, grants and how to access social services.

\section{Skills training and employment}

The NGO offers a six-month employment contract as a street sweeper with a City Improvement District (CID). The client has to volunteer consistently to do cleaning jobs and other tasks at the NGO's centre in order to be placed on the waiting list for this job.

Clients are also assisted to search for other jobs by helping them prepare résumés.

\section{Provision for spiritual needs}

The NGO has a second goal apart from helping homeless people live permanently off the street and this aim is to convert clients to Christianity. In order to receive the midday meal, clients must attend a religious service. This service consists of prayer, songs and a sermon.

\section{Programme theory}

The programme activities described above can be presented as a programme theory. Such a theory serves to "explain why the programme does what it does and provides the rationale for expecting that doing so will achieve the desired results" (Rossi, Lipsey \& Freeman, 2004:135). If the assumptions underlying the programme theory do not represent a credible approach to bringing about the intended results, it is unlikely that the programme will be effective (Rossi et al., 2004).

The theory underlying the NGO's programme to reduce homelessness is straightforward: if a client is given access to accommodation and employment, and is able to address the causes of his or her homelessness, then the client will leave the streets and reintegrate into society. The provision of accommodation, employment and psychosocial support is accompanied by the provision of food and basic hygiene. The theory behind the NGO's aim to convert people to Christianity is that if a person is told the gospel message, then he or she might convert. The NGO's programme theory was 
elicited by means of interviews with, and e-mails from, the programme manager and is depicted in Figure 1.

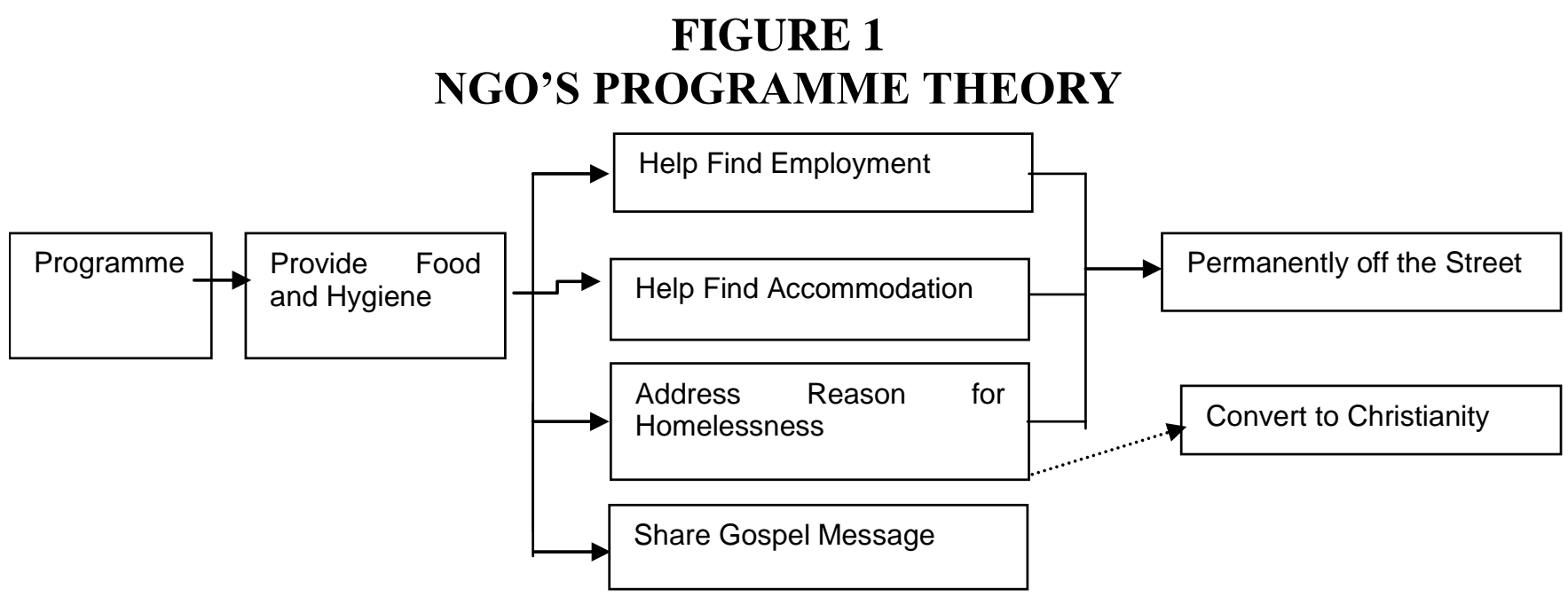

\section{Evaluating spiritual programmes}

Rossi et al. (2004:102) state that "in evaluating a social program, it is essential to ask whether it addresses a significant social need in a plausible way and does so in a manner that is responsive to the circumstances of those in need." It is doubtful that not being an adherent of Christianity constitutes a significant social need. Likewise, it is not clear how conversion is an action responsive to the circumstances of those in need.

Another problem with evaluating a programme which attempts to convert people to Christianity is that there is no way of objectively measuring if the outcome has been achieved. As a result of these two problems, this publication will not focus on the spiritual activities of the programme.

\section{Evaluation questions}

A programme theory provides the evaluator with a basis for formulating useful evaluation questions. The current evaluation is a process evaluation. In other words, it will attempt to discover "whether the program is delivered as intended to the target recipients" (Rossi et al., 2004:431). Any process evaluation is concerned with three programme areas, namely the programme's service utilisation, service delivery and organisational support (Rossi et al., 2004). Service utilisation refers to the extent to which the programme reaches its target audience, while a programme's service delivery refers to its ability to implement the programme as intended. The last evaluation area for a process evaluation is to examine whether the programme has enough resources to implement it as planned. Based on this, the following evaluation questions have been formulated:

\section{Service utilisation}

1. Who has utilised the programme's services?

2. Which programme services are the clients utilising? 
3. What are the clients' perceptions of services offered by the NGO?

4. What has assisted the clients who have entered the CID employment track to become success cases?

\section{Service delivery}

5. What are the actual programme activities? Were these the same as the intended activities?

6. How many clients use the NGO's services?

7. Are the activities delivered in an effective manner by the staff to enable clients to find employment, accommodation and to explore the reasons for homelessness?

8. Are the referral activities delivered in an effective manner so that clients can access primary health care, treatment and rehabilitation, social grants, and obtain an identity document?

9. Is the programme delivered according to social development standards?

10. Does the NGO adhere to the conditions stipulated by the CID for the employment of street people as street cleaners?

\section{Organisational support}

11. Does the NGO have sufficient resources (financial, human and infrastructure) to deliver the programme effectively?

12. How do the staff organise their activities? Do their efforts complement the activities?

\section{METHOD}

\section{Design}

This evaluation had a dual design. All evaluation questions except Evaluation Question 3 were answered within a descriptive framework. Babbie and Mouton (1998:105) define descriptive research as "the precise measurement and reporting of the characteristics of some population or phenomenon under study."

For Evaluation Question 3, however, an exploratory framework was used. This means that the answer to this question does not constitute a precise measurement. This question aimed to find out how clients perceive the services made available to them and the question is therefore an attempt to increase understanding. This meets the criterion of exploratory research which has been described as "the attempt to develop an initial, rough understanding of some phenomenon" (Babbie \& Mouton, 1998:105).

\section{Participants}

For Evaluation Questions 1-3 (Service Utilisation), all clients who made use of the NGO's services for the week of 22 June to 28 June 2011 were approached to answer structured questions $(n=37)$. Thirty-eight clients were interviewed but one interview containing ambiguous and meaningless answers was omitted. 
For Evaluation Question 4 (Service Utilisation), sampling was based on a variation of Brinkerhoff's (2003) Success Case Method (SCM). An assumption was made that the clients who had entered the CID employment track demonstrated that they had begun to utilise the employment opportunities offered by the NGO. They could therefore be deemed as success cases. Four success cases were interviewed.

Responses to Evaluation Questions 5-10 (Service Delivery) and Evaluation Questions 11-12 (Organisational Support) were provided by the programme manager.

\section{Materials}

\section{Evaluation Questions 1-3 (Service Utilisation)}

For the service utilisation questions, data were collected by means of structured interviews with the clients. It could not be assumed that the clients were literate and therefore a self-administered questionnaire was not appropriate. Babbie and Mouton (1998) note that an interview has a number of advantages over a self-administered questionnaire: it usually allows researchers to gather more responses; the interviewer can clarify confusing questions and if the interviewer is allowed to probe for answers, it can decrease the number of "don't know" answers. Although there might be some doubt regarding self-report data from the homeless, there is evidence that this population may report answers with some accuracy (Calsyn, Morse, Klinkebenberg \& Trusty, 1997; Gelberg \& Siecke, 1997). However, this accuracy is likely to decrease if the answers are complex or if the respondent feels that the answer will result in stigmatisation (Gelberg \& Siecke, 1997). Calsyn et al. (1997) and Schumacher et al. (1995) have cautioned that self-report results on mental health and substance abuse services are likely to be underestimates.

The implications of these studies are that the questions which are asked of the homeless should be fairly simple, the interviewer should avoid questions which are seen as potentially stigmatising and that the researcher needs to be aware that underestimates may occur in certain conditions. A checklist, which accommodated all these implications, was designed for the interviews. The checklist allowed the evaluator to determine the age and sex of the respondent and which services the respondent was utilising. It also allowed the evaluator to determine the clients' perceptions of the services utilised. The complete checklist is available from the evaluators.

\section{Evaluation Question 4 (Success Cases)}

This question was answered through structured interviews with clients who had entered the CID employment track. The interview was based on an outcome map, which is presented in Table 1. 


\section{TABLE 1 \\ OUTCOME MAP}

\begin{tabular}{|l|l|l|}
\hline Services Utilised & \multicolumn{1}{|c|}{$\begin{array}{c}\text { Outcome (Tick if } \\
\text { achieved) }\end{array}$} & Follow-up Question \\
\hline Worked as a volunteer at NGO & \multicolumn{2}{|c|}{} \\
\hline $\begin{array}{l}\text { Signed up for work as a CID } \\
\text { street sweeper }\end{array}$ & & $\begin{array}{l}\text { What type of job } \\
\text { did you look for? }\end{array}$ \\
\hline Worked as a CID street sweeper & $\begin{array}{l}\text { What type of job } \\
\text { did you find? }\end{array}$ \\
\hline Looked for another job & \multicolumn{2}{|c|}{ The following questions should be asked at the highest successful outcome: } \\
\hline Found another job & \\
\hline $\begin{array}{l}\text { 1. What has helped you achieve } \\
\text { this level of success? }\end{array}$ & \\
\hline $\begin{array}{l}\text { 2. How is your life different now? } \\
\text { 3. What has hindered you from } \\
\text { achieving this level of success? }\end{array}$ & $\begin{array}{l}\text { 4. How can the NGO help other } \\
\text { people achieve your level of } \\
\text { success? }\end{array}$ \\
$\begin{array}{l}\text { ITailor the question to reflect the achieved outcome. For example, if the highest success } \\
\text { outcome was that he/she worked as a street sweeper, then question 1 will be: what has helped } \\
\text { you become a street sweeper for the CID? }\end{array}$ \\
\hline
\end{tabular}

As is evident from the outcome map, the CID employment track consisted of five outcomes. The outcome map allowed the evaluator to determine which outcomes had been achieved. After determining the highest successful outcome, the evaluator asked designated follow-up questions of the participant.

The outcome map and follow-up questions were designed in an attempt to fill "success case interview buckets" (Brinkerhoff, 2003:142). The filling of these buckets allowed the evaluator to determine what factors had contributed to the participant becoming a success case. The first bucket sought to discover what aspects of the employment initiative they used. The second bucket sought to find out what outcomes were achieved, while the third bucket was used to find out what benefits the project had. Bucket four aimed to find out what aspects of their environment were used by success cases to achieve their success. The fifth bucket was optional and was a way for success cases to give suggestions for improvement of the project.

\section{Evaluation Questions 5-10 (Service Delivery)}

These evaluation questions were answered by means of an interview based on a service delivery checklist, which is available from the evaluators. The checklist allowed the evaluator to determine whether or not the intended activities were being delivered to clients. If the activities were being implemented as planned, the checklist allowed the evaluator to determine what percentage of clients was using these services. The checklist was also used to determine if the services had been used effectively. The interview did not cover a specific period of time (for example, the year to date), but it was designed to give an overview of service delivery in general. The checklist is available from the evaluators. 


\section{Evaluation Questions 11-12 (Organisational Support)}

The primary evaluator interviewed the programme manager on the basis of an organisational support checklist, which was designed to determine if there was sufficient funding, staff and infrastructure to support the activities. The organisational support checklist is available from the evaluators.

\section{Procedure}

The University of Cape Town's Ethics in Research Committee granted approval that the evaluation could be carried out. The programme manager of the NGO granted written permission for a process evaluation. The programme manager also reviewed and approved all the checklists. Client participants remained anonymous and all participation was on a voluntary basis. Participants who agreed to participate were given a food package sponsored by the primary evaluator.

\section{Evaluation Questions 1-3 (Service Utilisation)}

The programme manager introduced the evaluator to the clients and informed them that the evaluation was offered to the NGO free of charge and that it was intended to benefit the organisation. The programme manager stressed that the evaluator was trustworthy and that participation was voluntary.

The interviews were not recorded as the act of recording might have been intimidating to the respondents.

\section{Evaluation Question 4 (Success Cases)}

The success case interviews took place after the service utilisation interviews.

\section{Evaluation Questions 5-10 (Service Delivery) and 11-12 (Organisational Support)}

The evaluator interviewed the programme manager and recorded his responses on the checklist.

\section{RESULTS}

Despite the guidelines followed for designing data-collection tools for the homeless, it should be noted that the data-collection process for this sample was onerous. As will become clear from the paucity of the reported results, the participants provided a minimum of data. Despite probing, participants often did not give direct answers to the interview questions. The primary evaluator adapted his interview style and frequently replaced words on the checklist with synonyms. Researchers wishing to study this population should be aware of the difficulties of collecting valid and reliable data.

The evaluation questions formulated earlier will be used to present the subsections of the results.

\section{Service Utilisation}

Evaluation Question 1: Who has utilised the non-governmental organisation's services?

The majority of the respondents were male. There were $28(75.7 \%)$ male respondents and nine female respondents. 
The mean age of the respondents was $35.6(n=35)$. Two instances where the age of the respondent was not known were omitted from the calculation. The mean age for the women was 29.1 years, while the mean age for the men was 37.9.

Evaluation Question 2: Which programme activities are the clients utilising? Which activities were not sufficiently utilised?

Table 2 presents the services offered by the NGO and the extent to which clients accessed these services.

\section{TABLE 2}

UTILISATION OF THE NGO'S SERVICES

\begin{tabular}{|l|rl|}
\hline Service & Respondents Using Service (n=37) \\
\hline Meals & 36 & $(98.2 \%)$ \\
Showers & 24 & $(64.9 \%)$ \\
Lockers & 19 & $(51.4 \%)$ \\
Wash clothes & 16 & $(43.2 \%)$ \\
\hline Core Services & \multicolumn{2}{|c|}{} \\
\hline Build a Shelter & \multicolumn{2}{|c|}{$(10.8 \%)$} \\
Find Accommodation & 8 & $(21.6 \%)$ \\
Volunteer at LG & 22 & $(62.9 \%)^{\mathrm{a}}$ \\
Sign up for CID contract & 14 & $(37.8 \%)$ \\
Work at CID & 10 & $(27.0 \%)$ \\
Discuss homelessness & 15 & $(41.7 \%)^{\mathrm{b}}$ \\
See social worker/staff regularly & 17 & $(46.0 \%)$ \\
\hline Reference Services & \multicolumn{2}{|c|}{} \\
\hline Social grant & 4 & $(11.1 \%)^{\mathrm{b}}$ \\
Clinic & 14 & $(37.8 \%)$ \\
Drug counselling & 19 & $(51.4 \%)$ \\
Alcohol counselling & 6 & $(16.2 \%)$ \\
ID book & 19 & $(51.4 \%)$ \\
\hline
\end{tabular}

${ }^{a} n=35$. Two of the respondents worked for the NGO and therefore their responses were omitted from the total number of respondents.

${ }^{b} \mathrm{n}=36$. There was one response which was unclear and it was therefore omitted.

If an arbitrary cut-off point of $50 \%$ is used, then the following services were not sufficiently utilised: wash clothes; build a shelter; sign up for CID contract; work at CID; discuss homelessness; see social worker/staff member regularly and referrals to obtain a social grant, clinics and alcohol counselling. 
Evaluation Question 3: What are the clients' perceptions of services offered by the programme?

Table 3 presents client perceptions of the services offered by the programme.

Again, if an arbitrary cut-off point of 50\% is used, then clients had positive perceptions of every service except the referral to alcohol counselling. Only six of 37 (33.3\%) respondents indicated that this service was helpful.

TABLE 3

CLIENT PERCEPTIONS OF PROGRAMME'S SERVICES

\begin{tabular}{|l|c|c|}
\hline Service & $\begin{array}{c}\text { Respondents Using } \\
\text { Service }\end{array}$ & $\begin{array}{l}\text { Positive } \\
\text { Perception }\end{array}$ \\
\hline Initial Activities & & $33(91.7 \%)$ \\
Meals (good) & 36 & $24(100 \%)$ \\
Showers (clean) & 24 & $18(100 \%) \mathrm{a}$ \\
Lockers (safe) & 18 & $11(68.8 \%)$ \\
Wash clothes (good) & 16 & $3(75 \%)$ \\
\hline Core Services & & $7(87.5 \%)$ \\
\hline Build a shelter (easy) & 4 & $14(100 \%)$ \\
Find accommodation (easy) & 8 & $7(70 \%)$ \\
Sign up for CID contract (easy) & 14 & $13(86.7 \%) \mathrm{b}$ \\
Work at CID (easy) & 10 & $16(94.1 \%)$ \\
Discusses homelessness (helpful) & 15 & $2(50 \%) \mathrm{b}$ \\
See social worker/staff regularly (helpful) & & $14(100 \%)$ \\
\hline Reference Activities & 4 & $12(63.1 \%)$ \\
\hline Social grant (Easy to Obtain) & 14 & $2(33.3 \%)$ \\
Clinic (helpful) & 19 & $11(57.9 \%)$ \\
Drug counselling (helpful) & 6 & \\
Alcohol counselling (helpful) & 19 & (1) \\
ID book (easy to obtain) & & \\
\hline Note. The word used in the questions
\end{tabular}

Note. The word used in the questionnaire to describe the quality of the service is included in brackets.

${ }^{a} n=36$. There is one instance of missing data: a client indicated that he had used a locker, but his perception of the locker remains unclear. His response has been excluded.

${ }^{b} \mathrm{n}=36$. One of the responses by the client was unclear and it was therefore omitted from the analysis.

Evaluation Question 4: What assisted the clients who have entered the City Improvement District employment track to become success cases?

Table 4 presents the questions asked of four success cases. Their answers are given under each question. 


\section{TABLE 4 \\ SUCCESS CASE RESPONSES}

\begin{tabular}{|l|}
\hline Question 1: What has helped you to become a street sweeper? \\
Respondent 1: Persistence in arriving at [the NGO] \\
Respondent 2: [The NGO] and volunteering \\
Respondent 3: It is the only thing can keep me going. Volunteering. \\
Respondent 4: [Names of two staff members] encouraged me. \\
\hline Question 2: How is your life different now? \\
Respondent 1: I feel alright now. \\
Respondent 2: 100\% different through love of God. I'm off drugs. \\
Respondent 3: I was not relaxful (sic) before. I am now stable. \\
Respondent 4: Everyone knows me now. \\
Question 3: What has hindered you from becoming a street sweeper? \\
Respondent 1: Nothing. \\
Respondent 2: No. \\
Respondent 3: Nothing \\
Respondent 4: Nothing \\
Question 4: How can [the NGO] help other people become street sweepers? \\
Respondent 1: I can't say. \\
Respondent 2: [The NGO] can be honest and caring. You must believe in yourself. You \\
must make your mind open using God's Word. \\
Respondent 3: Become helpers and get [the NGO] to work with you. \\
Respondent 4: By volunteering.
\end{tabular}

When asked what has helped them get employment as a street sweeper, three of the four respondents indicated that either volunteering at the NGO or consistent presence at the premises had helped.

All four respondents indicated that their lives were different after receiving employment, but it was unclear if Respondent 2 was indicating that employment had made the difference or if it was the result of other factors.

None of the respondents were able to identify hindrances in obtaining employment and there were mixed responses as to how the NGO could have helped other people to become street sweepers.

\section{Service Delivery}

Evaluation Question 5: What are the actual programme activities? Were these the same as the intended activities?

Table 5 presents all of the NGO's activities and whether or not the programme manager believed that they had been delivered. For each activity which had been delivered, the programme manager also indicated whether he believed that the programme was delivered effectively. The estimated number of clients who used these services is also included. 
TABLE 5

EFFECTIVE DELIVERY OF SERVICES AND ESTIMATED USAGE OF SERVICES

\begin{tabular}{|c|c|c|c|}
\hline Intended Activities & Actual Activities & Effective Delivery & $\%$ \\
\hline Services & Delivered & $\underline{\text { Effective }}$ & $\begin{array}{c}\text { Estimated } \\
\frac{\text { Percentage of clients }}{\text { using service }}\end{array}$ \\
\hline \multicolumn{4}{|l|}{ Initial Services } \\
\hline Meals & Yes & Yes & $100 \%$ \\
\hline Showers & Yes & Yes & $33 \%$ \\
\hline Lockers & Yes & Yes & $33 \%$ \\
\hline Wash clothes & Yes & Yes & $15 \%$ \\
\hline \multicolumn{4}{|l|}{ Core Activities } \\
\hline Build shelter & No & No & - \\
\hline Find accommodation & Yes & Unknown & $5 \%$ \\
\hline Volunteer at centre & Yes & Yes & $10 \%$ \\
\hline CID employment & Yes & Yes & 7 clients $/ 6$ months \\
\hline Psychosocial & Yes & Unknown & Fluctuates \\
\hline Counselling & Yes & Unknown & $2 \%$ \\
\hline Long-term support & No & No & - \\
\hline Seeing a social worker & & & \\
\hline \multicolumn{4}{|l|}{ Referral Activities } \\
\hline Social grant & Yes & Yes & $2 \%$ \\
\hline Clinic & Yes & Yes & $5 \%$ \\
\hline Drug counselling & Yes & Yes & $10 \%$ \\
\hline Alcohol counselling & Yes & Yes & $10 \%$ \\
\hline ID book & Yes & Yes & $2 \%$ \\
\hline
\end{tabular}

According to Table 5, the programme manager was under the impression that all of the initial and referral activities were delivered in an effective manner. Only two of the core services were delivered effectively and these were related to the provision of employment as CID street sweepers.

Evaluation Question 6: How many clients use the non-governmental organisation's services?

Table 6 presents the comparison between the programme manager's estimates of how many clients used each service per month, and the respondents' indicated usage.

The programme manager estimated that the initial services were the most used services and this was confirmed by the clients. However, and with the exception of the provision of meals, there was a large discrepancy between the estimated and recorded rates of utilisation for each activity. In each case, the estimated rate of utilisation is lower than the recorded rate. Note that the estimate of service utilisation was based on the number of clients using a service each month, while the recorded rate did not take into account a time frame. 


\section{TABLE 6 \\ COMPARISON OF ESTIMATED AND RECORDED SERVICE UTILISATION}

\begin{tabular}{|l|c|c|}
\hline \multicolumn{1}{|c|}{ Activities } & $\begin{array}{c}\text { Estimated Percentage of } \\
\text { Service Utilisation } \\
\text { (Programme Manager) }\end{array}$ & $\begin{array}{c}\text { Recorded Percentage of Service } \\
\text { Utilisation } \\
\text { (Clients) }\end{array}$ \\
\hline Initial Services & & $98.2 \%$ \\
\hline Meals & $100 \%$ & $64.9 \%$ \\
Showers & $33 \%$ & $51.4 \%$ \\
Lockers & $33 \%$ & $43.2 \%$ \\
Wash Clothes & $15 \%$ & \\
\hline Core Activities & & $10.8 \%$ \\
\hline Build shelter & Not delivered & $21.6 \%$ \\
Find accommodation & $5 \%$ & $62.9 \%$ \\
Volunteer at NGO & $10 \%$ & $27.0 \%$ \\
CID employment & 7 clients/6 months & \\
\hline Referral Activities & & $11.1 \%$ \\
Social grant & $2 \%$ & $37.8 \%$ \\
Clinic & $5 \%$ & $51.4 \%$ \\
Drug counselling & $10 \%$ & $16.2 \%$ \\
Alcohol counselling & $10 \%$ & $51.4 \%$ \\
ID book & $2 \%$ & \\
\hline
\end{tabular}

Evaluation Question 7: Are the activities delivered in an effective manner by the staff to enable clients to find employment, accommodation and to explore the reasons for homelessness?

According to the programme manager, every initial service was delivered in an effective manner to the clients (Table 5). Two core activities, the provision of opportunities to volunteer and to work as a CID street sweeper, were delivered in an effective manner. Another two core activities (the provision of a shack and seeing a social worker) were not delivered at all. The programme manager did not know if the provision of accommodation, psychosocial counselling and long-term support were effective.

Evaluation Question 8: Are the referral activities delivered in an effective manner so that clients can access primary health care, treatment and rehabilitation, access social grants, and obtain an identity document?

The programme manager reported that all of the referral services were delivered effectively (Table 5).

Evaluation Question 9: Is the programme delivered according to social development standards?

The Department of Social Development does not place onerous demands upon nongovernmental organisations. According to the programme manager, the NGO does ensure that it adheres to the mandated fiscal control policies and occupational health demands.

Evaluation Question 10: Does the programme adhere to the conditions stipulated by the City Improvement District for the employment of street people as street cleaners? 
The NGO provided a weekly report to representatives from the CID and ensures that it adheres to contractual obligations.

\section{Organisational support}

Evaluation Question 11: Does the non-governmental organisation have sufficient resources (financial, human and infrastructure) to deliver the programme effectively?

Table 7 presents the activities offered by the NGO and the programme manager's perception of whether or not these activities were supported by sufficient staff, budget and infrastructure.

TABLE 7

RESOURCE ALLOCATION FOR ACTIVITIES

\begin{tabular}{|c|c|c|c|}
\hline Activities & Sufficient Staff & $\begin{array}{l}\text { Sufficient } \\
\text { Budget }\end{array}$ & $\begin{array}{l}\text { Sufficient } \\
\text { Infrastructure }\end{array}$ \\
\hline \multicolumn{4}{|l|}{ Initial Services } \\
\hline Meals & Yes and $\mathrm{No}^{\mathrm{a}}$ & No & Yes \\
\hline Showers & Yes & Yes and $\mathrm{No}^{\mathrm{b}}$ & Yes \\
\hline Lockers & Yes & Yes & Yes \\
\hline Wash clothes & Yes & Yes and $\mathrm{No}^{\mathrm{c}}$ & Yes \\
\hline \multicolumn{4}{|l|}{ Core Activities } \\
\hline Build shelter & No & No & No \\
\hline Find accommodation & Yes & No & Yes \\
\hline Volunteer at NGO & Yes & Yes & Yes \\
\hline CID employment & Yes & Yes & Yes \\
\hline Psycho-social counselling & No & No & No \\
\hline Long-term support & No & No & No \\
\hline Case management & No & No & No \\
\hline \multicolumn{4}{|l|}{ Referral Activities } \\
\hline Social grant & No & No & No \\
\hline Clinic & Yes & Yes & Yes \\
\hline Drug counselling & Yes & Yes & Yes \\
\hline Alcohol counselling & Yes & Yes & Yes \\
\hline ID book & Yes & No & No \\
\hline
\end{tabular}

${ }^{\mathrm{a}}$ The NGO depends on volunteers to help provide meals and without volunteer support it would not be able to provide this service.

${ }^{\mathrm{b}}$ There is insufficient budget to provide soap to clients but the shower is always available for use.

${ }^{\mathrm{c}}$ There is insufficient budget to provide washing powder to clients but the facilities are available for clients to use.

Table 7 shows an organisation which is significantly under-resourced. The NGO did not have sufficient staff, budget or infrastructure to run their programme as planned.

Evaluation Question 12: How do the staff organise their activities? Do their efforts complement the activities?

According the programme manager, the staff spent most of their time involved in food management and preparation. The collection and distribution of donations was the 
second most time-consuming activity. The third most time-consuming activity was the counselling of clients in one-on-one settings.

In summary, the results relating to service utilisation indicated that the programme's clients were mostly male and that they had generally favourable perceptions of the services offered to them. The clients made use of a mixture of initial, core and referral services. The results relating to service delivery suggested that all of the initial and referral activities were implemented as planned. However, there were two core services which were not delivered at all (build a shelter and seeing a social worker), and three core services which were delivered but not in an effective way (find accommodation, psychosocial counselling, long-term support). Finally, the NGO did not have sufficient resources to implement the programme as planned.

\section{DISCUSSION}

The programme areas which constitute a process evaluation will be utilised to present the discussion.

\section{Service Utilisation}

All participants were over the age of 16 and thus fit the age specification of the intended target population. The men were significantly older than the women. This is in contrast with the results of studies by Kok, Cross and Roux (2010) and Olefumi (1999), which showed no age difference. In the current evaluation one can only speculate that homelessness affects men and women at different stages of their lives or that men remain homeless for longer than women.

There were significantly more men than women. This is in line with a survey conducted by Kok et al. (2010), which found that there were more homeless men than women in South Africa. The reason for this gender discrepancy is unclear. It could be that women spend less time on the street because the streets are not perceived to be safe (Kok et al., 2010). Another possible reason is that the pathways into homelessness may affect men more than women.

One implication of having a male-dominated population is that the NGO may be able to tailor their services to problems which are more likely to affect the male homeless. For example, coloured homeless men are more likely to experience high blood pressure, cholesterol, diabetes, emphysema or bronchitis and TB when compared to the general population of South Africa (Seager \& Tamasane, 2010).

From the results of the evaluation it was unclear whether all of the participants were indeed homeless and therefore it is not known to what extent the NGO reached its target audience. It should be noted that the NGO has opened up the rehabilitation centre on its premises to the local community. Clients who are not homeless, but utilise the rehabilitation centre, can access the same services as the homeless. No client is requested to identify whether he or she is homeless or from the local community. This coverage is admirable, but has implications for funding and service delivery. 
As regards utilisation of initial services, the provision of meals was the most utilised service. Of all the services made available to clients, the provision of food is one which is most obviously related to survival. The only initial service which was not sufficiently utilised was the option to wash clothes at the centre. According to the programme manager, this under-utilisation is possibly due to the fact that washing powder is not always freely available to clients.

The only core service which was sufficiently utilised was the opportunity to volunteer at the centre. This may be due to the fact that clients are often given additional food if they volunteer. It may also be because it was one of only two core services which had sufficient staff, budget and infrastructure to implement as planned (Table 7). Although less than half the participants utilised the CID employment scheme, this activity should be considered fully subscribed, given that only seven clients are employed at any given time. Therefore the only two core services which were fully utilised were those which had sufficient staff, budget and infrastructure (Table 7).

It is worrisome that the core activities which are central to getting participants off the street, namely building a shelter and seeing a social worker, were not utilised sufficiently. The programme manager reported that although there was a fund for building shelters in previous years, there was no budget for this in 2011. No social worker was appointed because of lack of funding.

The NGO has had mixed success in its attempts to refer clients to additional services. The referrals for drug rehabilitation and referrals to obtain identity documents were both sufficiently utilised, but the remaining three referral activities (social grants, clinic and alcohol rehabilitation) were under-utilised.

There does not seem to be a direct link between the referral service utilisation and the resourcing of these services. For example, the referral to obtain an ID document was sufficiently utilised, but there was insufficient budget or infrastructure to implement the serviced as planned. Conversely, the referral to a clinic was insufficiently utilised, but this service was sufficiently resourced.

Client perceptions of the programme services were mostly positive (Table 3 ). The initial services were especially well received by clients, with three of the four services having approval rates above $90 \%$. The core services all had approval ratings of $70 \%$ or above, which suggests that the NGO offered these services in way which was easy for clients to access or in a way which clients found helpful. However, it should be noted that the NGO did not offer two of these core services (building a shelter and seeing a social worker). The only referral service to receive less than $50 \%$ approval was that of the referral to alcohol rehabilitation. It would be unwise to read too much into this particular result, given that only six respondents indicated that they had been referred for alcohol rehabilitation.

In summary, it is unclear whether the actual audience of the programme conformed to the guidelines for the intended audience, mainly because it could not be ascertained whether all participants were the street homeless. Clients utilised most of the initial services and specifically the provision of meals. Two of the most crucial core services, 
building a shelter and seeing a social worker, were not utilised as these were not offered because of a lack of funding. The NGO had mixed success as regards the utilisation of its referral services. Client perceptions of the programme services were mostly positive.

\section{Success Cases}

During the interviews with the success cases, it often seemed as if clients did not always understand what was being asked of them and this was especially true of the question which asked them to identify factors which helped them obtain employment as street sweepers.

The question that elicited the most useful data was the one that asked respondents if their life was different once they had begun working for the CID. The opportunity to work as a street sweeper has seemingly had a positive effect on these clients.

Clients were unable to identify any hindrances to becoming employed as a street sweeper. Respondents were also asked how the NGO could help other clients obtain employment as street sweepers. These answers are of limited value and there is little data which the NGO can use to improve its programme.

\section{Service Delivery}

The NGO did not carry out two of the planned core activities (Table 5), namely building a shelter and seeing a social worker. Both of these activities were reported to be significantly under-resourced. The absence and resourcing of these activities are likely to hinder the NGO's attempts to help clients leave a life on the streets. It is of some concern that those services which are fundamental to the programme theory are not delivered.

The exact number of clients using the NGO's services is unknown. The results of the research showed that there was a difference between estimated usage and recorded usage (Table 5), but this difference was probably due to different time frames. What is clear is that the programme manager was correct in his estimation that initial services would be the most utilised. The fact that the services which offer immediate and tangible benefits are the most utilised suggests that clients have their focus on present concerns and are less concerned with long-term goals.

Given that so little is known of South Africa's homeless population, it is unclear if the NGO's services are under- or over-utilised when compared to the other homeless organisations in South Africa. According to Sanchez (2010), faith-based organisations which help the homeless have dramatic differences in the number of people they help. For example, he mentions that one organisation helps 20 people per week, while another organisation in the same metropolitan area helps 600-700 people per week.

As regards effective service delivery, the NGO has provided employment to a limited number of clients in an effective manner (Table 5). However, it is not known how successful the organisation is in helping clients find employment outside of the CID employment track. 
The NGO did not offer clients the option to build a shelter. However, the NGO did help clients find accommodation through other means. Lack of monitoring data precludes a firm interpretation regarding the success of the latter activity.

The effectiveness of the psychosocial support was not known. When asked about counselling, respondents gave the impression that the counselling was fairly informal and that it was not a regular occurrence.

The programme manager indicated that all of the referral services were delivered effectively (Table 5). This seemed to be confirmed by the fact that all referral activities, apart from the referral for alcohol addiction, were viewed in a positive light by the clients (Table 3 ).

The programme manager stated that the programme was delivered according to the legal requirements of the Department of Social Development. A brief search of the Department of Social Development's (2011) database confirmed the NGO's registration with the department and submission of annual financial reports.

The CID requires a weekly report from the NGO. The programme manager confirmed that such a report was delivered every week.

In summary, the results obtained for service utilisation are reinforced by the results of service delivery. Again, it was unclear whether the actual recipients were the street homeless. Two of the intended core services, building a shelter and seeing a social worker, were not implemented because of lack of funding. There was a discrepancy between participants' reported usage of services and the programme manager's estimation of such usage. CID employment was deemed to be provided in an effective manner, but it is unclear whether other employment was provided effectively. The service relating to building a shelter was absent. Psychosocial support seemed to have been provided in an informal manner. All referral activities seemed to be provided effectively, with the exception of referral for alcohol addiction. The programme was delivered according to the requirements of the Department of Social Development and conformed to the reporting requirements of the CID.

\section{Organisational Support}

The programme manager stated that there were only 6 out of 16 activities which had sufficient staff, budget and infrastructure to implement as planned (Table 7). This would suggest that the NGO is significantly under-resourced and that it may be prudent to focus on fundraising in order to obtain the necessary resources to implement the programme as planned. Despite this lack of resources, a minimum 11 of the 16 activities were considered to be delivered effectively (Table 7). This would suggest that the NGO is achieving successes in certain activities (for example, the provision of meals) despite its limited resources.

According the programme manager, the staff spent most of their time on the most timeconsuming and most utilised service, namely food management and preparation. The collection and distribution of donations is the second most time-consuming activity. The third most time-consuming activity is the counselling of clients in one-on-one settings. 
In summary, the NGO is not implementing its programme as planned. The lack of sufficient resources has prevented the implementation of key activities and this is likely to prevent the NGO from achieving its goal of helping the homeless reintegrate into mainstream society. There is, however, reason for the NGO to be optimistic. The lack of resources has only prevented a minority of services from being delivered and the clients have a generally favourable perception of the services offered to them. Should the NGO have sufficient resources, it seems likely that the programme could be implemented as intended.

\section{Suggestions for improving the programme}

Ferguson and Heidemann (2009) observed that NGOs operate in resource-deprived environments which pose many challenges to service provision. This was also the case with the programme under evaluation. However, despite operating in a resourcedeprived environment, the NGO provided some services effectively and to the satisfaction of its clients.

At this stage it is not known whether more funding for the NGO's homeless programme would be forthcoming in the future. Based on this uncertain environment, the evaluators would like to provide the programme staff with two future scenarios for the programme. The first scenario focuses on a programme which provides short-term, initial services, limited referral services and can operate on limited funding. The second scenario sketches a multi-dimensional intervention in which a social worker will play a pivotal role. This latter scenario requires substantial funding.

The limited programme will focus on those initial activities which the NGO does well, namely provide food and a place to shower, store and wash clothes. Table 2 indicated that referrals for social grants, clinics and alcohol counselling were under-utilised. The evaluators suggest that all under-utilised referral services be discontinued, but that referrals for drug counselling and IDs should be retained. The main aim of this limited programme will be to provide temporary relief and survival services to the street homeless.

For the multi-dimensional programme, the evaluators reviewed literature on existing, successful programmes for the street homeless. It should be noted that while there are many publications which describe the lot of the homeless, very few evaluations of successful programmes are available. This lack of evaluations is not surprising as O'Connell, Blanchfield, Judge, Koh, Oppenhiemer, Swain and Taube (2010:147) note that "the paucity of evidence-based studies, inconsistent definitions of homelessness, a lack of consistent and incomparable data collection, and difficulties with long-term follow-up are major challenges to the evaluation of effective models of care for homeless populations." The exception to the lack of evidence is the four evaluations of complex, successful programmes for the homeless which are discussed below.

Busch-Geertsema's (2002) evaluation focuses on two projects for the provision of housing to end homelessness in Germany. Underlying these projects was the idea that homeless people should be provided with affordable formal housing which is adequately 
constructed. The participants were also provided with the support of a social worker and other services if so desired.

The first project was located in Bielefeld. The majority of participants were housed in single-dwelling units and provided with intensive support, with the aim that this support would be reduced over a five year period. The aim of the support was independence so that the participants were able to function without any additional help. It should be noted that participants were men who had significant problems and were considered unlikely to integrate into permanent housing with ease.

The second project Busch-Geertsema (2002) reported on was located in Hannover. Unlike the project in Bielefeld, this project housed both men $(n=9)$ and women $(n=3)$ in single-dwelling unit. All the participants had social problems. The participants were able to access support services offered by different agencies. A social worker met with the clients at least once a month and was contactable if a crisis arose. The results showed that over $90 \%$ of the participants managed to remain in the accommodation provided. However, the majority of the residents remained in poverty and were unemployed. As a result, some of the participants were unable to pay rent and might have been forced to return to the street, if social services had not intervened. The sustainability of this approach was in doubt unless the participants had access to funding or employment.

In another evaluation, focusing on housing in New York City, Tsemberis, Gulcur and Nakae (2004) assessed the longitudinal effects of a Housing First programme. This programme was aimed at homeless, mentally ill individuals. The evaluation examined the preferences, housing stability, substance use, treatment utilisation and psychiatric symptoms of the participants. Participants were assigned randomly to an experimental group (the Housing First group) or a control group (the Continuum of Care group). The Housing First initiative involved the provision of housing to mentally ill homeless people who were given access to social support through a modified form of Aggressive Community Treatment (ACT). The control group's treatment required participants to receive treatment while staying in transitional housing and then moving into permanent housing at a later stage. Support services were offered to the control group throughout the programme. This approach was based on the belief that homeless people were not capable of moving directly from the street into permanent accommodation.

The results showed that approximately $80 \%$ of participants in the experimental group were still living in mainstream society and the initiative was considered a success. This would suggest that providing immediate access to permanent accommodation would be of greater benefit than providing transitional accommodation.

Both of the above evaluations focused on housing provision as way to end homelessness. They suggest that homeless people are able to move directly into, and will benefit from, permanent residential accommodation. In both evaluations the accommodation provided to participants could be considered formal, habitable housing (Hall, 1999). There is evidence (Dworsky \& Piliavin, 2000) to suggest that the type of residence into which the homeless move has an impact on their likelihood of returning to homelessness. 
However, South Africa's housing situation is complex (Hall, 1999) and it is not clear what effect the different types of housing available will have on re-entry to homelessness. It may be that within a South African context, a shack is a practical option for housing the homeless. It has been argued that:

"Shacks may often meet some if not all of the requirements for catalysing selfsaving behaviour as a route out of poverty. If so, then existing shack housing is a rung on the accumulation ladder for those who have it, and may be an option for anyone - homeless or work-seeking - who needs accommodation with location advantage." (Cross \& Seager, 2010a:18)

A third evaluation by Rog (1999) focused on services-enriched housing. The Homeless Families Programme (HFP) aims to improve or create systems of care for the homeless and to grant access to services-enriched housing for homeless families experiencing difficulties. The programme was implemented in nine cities throughout the United States of America (USA). Homeless families who participated were given access to housing subsidies and support via a case management system. The programme was implemented by different organisations in each of the cities. The results of the evaluation suggest that there were multiple gaps in service delivery to the homeless and that where service delivery occurred, it was not uniform. However, the provision of a housing subsidy could help end homelessness. The results showed that $85 \%$ of participants in six of the nine cities were able to live in permanent accommodation for at least 18 months. There were insufficient data on the other three cities.

This evaluation is helpful in that it not only reinforces the role that permanent accommodation plays in helping end homelessness, but it also draws attention to case management. Rog (1999) states that the effectiveness of case management and other support services in contributing to housing stability are unclear. However, the fact that such a high rate of housing stability did occur is a significant achievement. In this evaluation, case management occurred over at least one year and other authors have also called for long-term social support (Drury 2008; Ji, 2006). Both of the evaluations which focused on housing (Busch-Geertsema, 2002; Tsemberis et al., 2004) encouraged the use of case management. For example, Busch-Geertsema (2002:14) states that:

"The dwelling alone is often not sufficient. Integrative support has the prior aim of maintaining dwellings, but a further integration into society cannot be achieved by maintenance of tenancies alone ... Case management and the use of regular social support (like advice centres for different problems such as indebtedness, addiction, health problems, etc.) are relevant in this context."

Goetz and Schmiege (1996) conducted an evaluation which focused on employment as a pathway out of homelessness. They evaluated the Homeless Employment and Related Training (HEART) project which was based in Oregon, USA. The authors sought to evaluate the role of job skills training, job search assistance and intensive case management in helping the homeless move into mainstream society.

Participants were trained by professionals in the construction industry and local contractors were contacted and encouraged to hire participants who completed the 
training. Throughout the training, participants were housed in local shelters and they were provided with transportation, clothing, food, medical care and work-appropriate footwear. They were also given psycho-social support in many forms. For example, participants were referred to outpatient rehabilitation centres, and given access to anger management classes and trained counsellors (Goetz \& Schmiege, 1996).

This programme was successful as over $60 \%$ of participants had found employment at the end of the programme and 65\% had moved into permanent housing (Goetz \& Schmiege, 1996). It should be noted that no long-term follow up was conducted and it is not known how effective the programme is over time.

Based on the above evaluation, it would seem that employment can be used to help homeless people leave a life on the streets. However, there appear to be certain conditions which the employment opportunities must meet in order to help clients get off the street. Firstly, there must be long-term support once the client is employed (Chamberlain \& Johnson, 2008; Goetz \& Schmiege, 1996; Hursch \& Schutt, 2009). Secondly, these employment opportunities must be close to available and accessible accommodation (Cross \& Seager, 2010a, 2010b) or the participants run the risk of losing their jobs due to poor performance. Goetz and Schmiege (1996) make it explicit that their participants were given accommodation because they did not want participants to have to worry about daily struggles while learning a new skill. They also argue for a third condition, which is that job training needs to be done in collaboration with industry stakeholders.

Thus far, the literature discussed has called for a multi-dimensional approach to solving homelessness. This is to be expected given that there is almost universal recognition that the solution to homelessness is certain to be complex (O'Connell et al., 2010; Shier, Jones \& Graham, 2010). The above evaluations and supporting literature reflect this complexity by showing that shelter, employment and long-term support are foundational to helping the homeless live off the street. Based on the literature presented here, a revised programme theory for an effective multi-dimensional programme has been designed by the evaluators and is depicted in Figure 2.

It should be noted that this programme theory focuses on three main areas, namely housing, employment and case management. All of these areas require substantial funding and a monitoring system which can track implementation fidelity and outcome progress. Should the NGO adopt the latter scenario, a concerted effort to raise funds is required. 
FIGURE 2

REVISED PROGRAMME THEORY

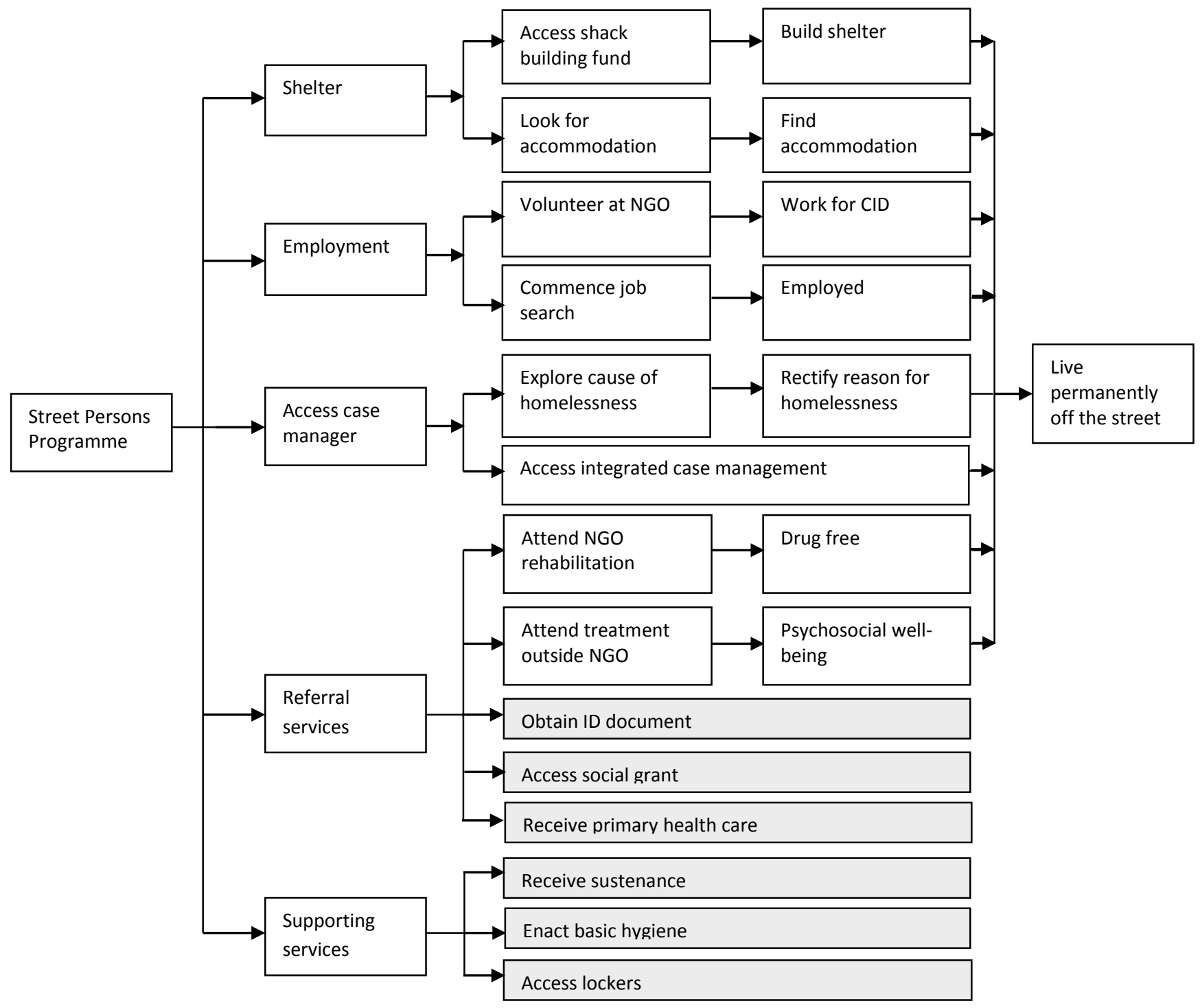

The evaluators also suggest that research be undertaken to provide the NGO with sufficient information to make an informed decision regarding the type of case management which would be appropriate for this context. Models of case management range from intensive case management by professional social workers with low caseloads to case management aides supplying basic psychosocial counselling and coordination of different services for the homeless. In the programme theory presented above, case management is a crucial component - as is the case with all complex, multiservice programmes. It is unlikely that any multi-dimensional programme for the homeless would be successful without the element of case management. 


\section{CONTRIBUTION TO KNOWLEDGE}

The main contribution of this evaluation is its value to the NGO. It clearly shows what works and what does not work in the programme. Useful suggestions for down- or upscaling the programme are made.

Apart from this contribution, the evaluation constitutes the first evaluation of a South African homeless programme and necessarily contributes to the body of evaluation knowledge. It has highlighted the challenges of obtaining data from the homeless population. These challenges include the following facts: the population is transient, suspicious of authority figures, and may be poorly educated.

\section{LIMITATIONS}

This evaluation has a number of limitations. Firstly, a convenience sample was utilised. The results cannot therefore be generalised to the wider population of clients who utilise the NGO's services. While it would have been ideal to select a representative sample, there was no practical option apart from the convenience sample.

Secondly, the interview questions did not record reasons why clients did not make use of a service. As a result, there is no differentiation between those who did not receive the service and those who did not need to receive the service.

Thirdly, this evaluation has raised doubts about the adequacy of Brinkerhoff's (2003) SCM when it is applied the homeless. The SCM requires participants, firstly, to be able to analyse factors which have helped and hindered them, and secondly, to be able to communicate the results of this analysis to other people. It is unclear if homeless people have the requisite skills to perform these two tasks and therefore the SCM may not be a suitable research tool if it is applied to the homeless.

\section{CONCLUSION}

Homelessness is a social problem that is unique in its complexity. There are many routes into homelessness but very few out of it. Those who experience it, face a number of significant and potentially insurmountable problems, which range from poor physical and mental health to difficulties in obtaining help from the state. Those who wish to help the homeless have to implement a solution which is equally complex. It requires longterm commitment, willing staff, a plausible programme theory and a not inconsiderable amount of resources. It is this last requirement which is proving to be a hindrance to the NGO's success as it prevents the NGO from implementing its programme as planned. Until the NGO is able to implement the programme theory as planned, it seems likely that their homeless clients will remain skeletons at the feast.

\section{REFERENCES}

BABBIE, E. \& MOUTON, J. 1998. The practice of social research. Cape Town: Oxford University Press.

BRINKERHOFF, R.O. 2003. The success case method. San Francisco: Berrett Koehler Publishers Inc. 
BUSCH-GEERTSEMA, V. 2002. When homeless people are allowed to decide by themselves. Rehousing homeless people in Germany. European Journal of Social Work, 5:5-19.

CALSYN, R.J., MORSE, G.A., KLINKENBERG, D. \& TRUSTY, M.L. 1997. Reliability and validity of self-report data of homeless mentally ill individuals. Evaluation and Program Planning, 20:47-54.

CROSS, C. \& SEAGER, J. (with ERASMUS, J., O'DONOVAN, M. \& WARD, C.) 2010a. Skeletons at the feast: a review of street homelessness in South Africa and other world regions. Development Southern Africa, 27:5-20.

CROSS, C. \& SEAGER, J. 2010b. Towards identifying the cause of South Africa's street homeless: some policy recommendations. Development Southern Africa, 27:143-158.

CHAMBERLAIN, C. \& JOHNSON, C. 2008. From youth to adult homelessness. Australian Journal of Social Issues, 43:563-582.

DEPARTMENT OF SOCIAL DEVELOPMENT. 2011. Database Search Menu. [Online] Available: http://www.dsd.gov.za/npo/.

DRURY, L.J. 2008. From homeless to housed: caring for people in transition. Journal of Community Health Nursing, 25:91-105.

DWORSKY, A.L. \& PILIAVEN, I. 2000. Homeless spell exits and return: substantive and methodological elaboration on recent studies. Social Services Review, 74:193-213.

FERGUSON, K.M. \& HEIDEMANN, G. 2009. Organizational strengths and challenges of Kenyan NGOs serving orphans and vulnerable children: a template analysis. International Journal of Social Welfare, 18:354-364.

GELBERG, L. \& SIECKE, N. 1997. Accuracy of homeless adults' self-reports. Medical Care, 35:287-290.

GOETZ, G.W. \& SCHMIEGE, C.J. 1996. From marginalized to mainstreamed: the HEART project empowers the homeless. Family Relations, 45:375-379.

HALL, K. 1999. Children's access to housing. In: PENDLEBURY, S., LAKE, L. \& SMITH, C. (eds) South African Child Gauge 2008/2009. Cape Town: Children's Institute, University of Cape Town, 98-99.

HERMAN, D.B., STREUNING, E.L. \& BARROW, S.M. 1994. Self-reported needs for help among homeless men and women. Evaluation and Program Planning, 17:249256.

HURSCH, N.C. \& SCHUTT, R.K. 2009. Influences on job retention among homeless persons with substance abuse or psychiatric disabilities. Journal of Sociology and Social Welfare, 36:53-73.

JI, E. 2006. A study of the structural risk factors of homelessness in 52 metropolitan areas in the United States. International Social Work, 49:107-117. 
KOK, P., CROSS, C. \& ROUX, N. 2010. Towards a demographic profile of the street homeless in South Africa. Development Southern Africa, 27:21-37.

OLEFUMI, O. 1999. Health of the homeless street women in South Africa. Habitat International, 23:481-493.

O'CONNELL, J., BLANCHFIELD, B.B., JUDGE, C.M., KOH, H.K., OPPENHIEMER, S.C., SWAIN, S.E. \& TAUBE, R.L. 2010. The Boston health care for the homeless program: A public health framework. American Journal of Public Health, 100:1400-1408.

ROG, D.J. 1999. The evaluation of the homeless families program. American Journal of Evaluation, 20:558-561.

ROSSI, P.H., LIPSEY, M.W. \& FREEMAN, H.E. 2004. Evaluation. A systematic approach. Thousand Oaks: Sage Publications.

SANCHEZ, D. 2010. Civil Responses to homelessness. Development Southern Africa, 27:101-110.

SEAGER, J.R. \& TAMASANE, T. 2010. Health and well-being of the homeless in South African cities and towns. Development Southern Africa, 27:63-83.

SCHUMACHER, J.E., MILBY, J.B., RACZYNSKI, J.M., CALDWELL, E., ENGLE, M., CARR, J. \& MICHAEL, M. 1995. Validity of self-reported cocaine use amongst homeless persons in treatment. Journal of Substance Abuse Treatment, 12:335-339.

SHIER, M.L., JONES, M.E. \& GRAHAM, J.R. 2010. Turnaround points: the role of help seeking and service delivery for employed people experiencing homelessness in Calgary, Canada. Social Development Issues, 32:50-64.

TSEMBERIS, S., GULCUR, L. \& NAKAE, M. 2004. Housing First, consumer choice, and harm reduction for homeless individuals with a dual diagnosis. American Journal of Public Health, 94:651-656.

Mr Kevin O'Donoghue, Master's student; Prof Joha Louw-Potgieter, Section of Organisational Psychology, University of Cape Town, Cape Town, South Africa. 